\title{
Persistent Operating Losses and Corporate Financial Policies*
}

\author{
David J. Denis
}

Stephen B. McKeon ${ }^{* \bullet}$

September, 2017

\footnotetext{
We thank Harry DeAngelo, Diane Denis, Will Gornall, Matt Gustafson (discussant) David Haushalter, David McLean (discussant), Rene Stulz, and participants at the SFS Cavalcade, Florida State University Sun Trust Conference, University of Alberta Banff Frontiers of Finance Conference, Mississippi State University Magnolia Finance Conference, Pacific Northwest Finance Conference, Baruch University, NOVA School of Business and Economics, North Carolina State University, TCU, Tsinghua School of Economics and Management, Tsinghua PBC, University of Illinois-Chicago, University of Oklahoma, University of Porto, and University of Wisconsin, Milwaukee for helpful comments.

- Roger S. Ahlbrandt, Sr. Chair and Professor of Business Administration, University of Pittsburgh, djdenis@,katz.pitt.edu

- Asst. Professor of Finance, University of Oregon, smckeon@,uoregon.edu
} 


\title{
Persistent Operating Losses and Corporate Financial Policies
}

\begin{abstract}
Among U.S. firms, operating losses have become substantially more prevalent, persistent, and greater in magnitude since 1970. Loss firms now comprise over $30 \%$ of the Compustat universe and such losses continue for a median of four years. We find that firms with negative operating cash flows account for more than half of the rise in average cash balances over the sample period, with average cash holdings increasing by $580 \%$ for negative cash flow firms vs. $90 \%$ for positive cash flow firms. Further, firms exhibiting operating losses now comprise the majority of equity issuers. These companies issue frequently, primarily through private placements, and use the funds raised in the issue to cover subsequent operating losses. We conclude that the immediate and expected ongoing liquidity needs of firms with persistent operating losses have substantially altered corporate financial policies.
\end{abstract}




\section{Introduction}

A growing body of research reports secular changes in the composition of publicly traded U.S. companies. Over the past several decades, U.S. companies have evolved from being manufacturing entities to being more service and high-tech oriented (Kahle and Stulz (2016)). Coincident with this shift, U.S. companies spend less on capital expenditures and more on research and development (R\&D) so that intangible capital now comprises more than $50 \%$ of net assets for the average company (Falato, Kadyrzhanova, and Sim (2013)). Cash flows have also become more volatile and Bates, Kahle, and Stulz (2009) tie this increase in volatility to secular increases in average corporate cash holdings.

In this study, we explore the evolution of profitability among U.S. firms and show that not only have cash flows become riskier; they are now much lower for a considerable subset of U.S firms. In the 1950's about $2 \%$ of public firms listed in Compustat reported operating losses (defined as negative cash flow from operations on the firm's Statement of Cash Flow). In contrast, the period since 1980 has been characterized by an explosion in the percentage of public firms with negative cash flow (CF), rising from $9 \%$ in 1979 to over $30 \%$ in several recent years. Moreover, similar patterns exist even if we measure operating cash flow before R\&D expenditures have been deducted. Thus, the increased frequency of operating losses is not simply a byproduct of rising $\mathrm{R} \& \mathrm{D}$ expenditures over time.

We further show that for most firms in recent years, operating losses are not a transitory phenomenon. Firms that lose money on operations this period are likely to lose money next period as well. For example, less than a quarter of the firms that reported negative CF in 2015 subsequently reported positive CF in 2016, and the median 'run' of negative cash flow is four years. This persistence in operating losses is also a recent phenomenon; up until approximately 
1990, firms that reported an operating loss in one year had a greater than $50 \%$ chance of reporting positive operating earnings in the following year. Moreover, the magnitude of operating losses has grown substantially over time as well. In the 1970s, operating cash flow for firms in the bottom decile of operating cash flow exhibited losses equal to $11 \%$ of assets, on average. In the $2000 \mathrm{~s}$, these average losses for firms in the bottom decile have ballooned to $58 \%$ of assets.

Persistent operating losses create immediate and ongoing liquidity needs that must be met by existing internal resources or external finance (or both). We show that firms expecting such losses behave differently than firms with positive cash flow on several dimensions of corporate financial policy such as cash holdings, equity issuance frequency, and cash savings from issuance. Between 1970 and 2015, average cash holdings as a percentage of total assets increase by $90 \%$ for firms exhibiting positive cash flow. More strikingly, however, average cash holdings increase by $580 \%$ for firms with negative operating cash flow. Firms with negative cash flow account for more than half of the increase in average cash balances of U.S. firms reported in Bates, Kahle, and Stulz (2009).

Traditionally, the precautionary demand for cash has been framed within a context focused on the second moment of the distribution of cash flow. According to the precautionary savings theory of Keynes (1936), firms stockpile cash to protect themselves against adverse cash flow shocks because these shocks could lead to underinvestment. However, when the first moment of the cash flow distribution is negative, first moment considerations are likely to add substantially to the precautionary demand for cash. In such situations, it is plausible that the demand for cash stems more from the expected level of cash flow than from its volatility. Consistent with this view, we show that neither changes in cash flow volatility nor increases in $R \& D$ expenditures (two traditional proxies for the demand for precautionary cash) are sufficient to capture the additional 
amount of cash held by negative cash flow firms. For example, among the subsample of firms that comprise the top two deciles of R\&D spending, we find that the cash holdings of high cash flow firms have grown by $43 \%$ over our sample period, while cash holdings of low cash flow firms have grown by over $700 \%$.

We infer from this evidence that among the growing number of firms that exhibit persistent operational deficits, cash stockpiling for these firms is less about guarding against the possibility of a shock to financing needs or costs, and more about the fact that cash flow is negative right now and is likely to remain that way. In other words, the stockpile is not solely a precaution against the possibility of underinvestment induced by unexpected financing needs. It is a deliberate plan to finance near term operational needs under an expectation of negative cash flows.

To explore the source of cash stockpiles in firms with negative operating flows, we analyze external financing activity and asset sales and find that the relative proportions of each have changed substantially over time. In the 1970's, high CF firms mostly issued equity and low CF firms relied predominantly on debt. By contrast, in the most recent decade (2007-2016), low CF firms raise 17 times more equity capital than debt capital.

Consistent with Ritter and Welch's (2002) and Fama and French's (2004) evidence on new lists, we find that over the past four decades, negative cash flow firms represent an increasing proportion of firm-initiated equity issuances (IPOs, SEOs, and private placements). ${ }^{1}$ In every year but one since 1989, the majority of firms issuing equity report negative operating cash flows (CF). In the last year of our sample, 2016, negative CF issuers outnumber positive CF issuers 2 to 1 . In addition, we find that equity issues of firms with negative operating cash flow are overwhelmingly

\footnotetext{
${ }^{1}$ Firm-initiated equity issues are defined as stock issuances that exceed $3 \%$ of market equity. This definition captures the vast majority of IPOs, SEOs, and private placements while excluding most employee-initiated issuances such as ESPPs and the exercise of stock options (McKeon, 2015).
} 
private placements in recent years. Such private placements account for approximately $90 \%$ of the equity issues for negative cash flow firms in the last five years of our data. By contrast, the majority of equity issues for positive cash flow firms over the same period are seasoned equity offerings (SEOs).

Firm-initiated equity issues typically represent a substantial cash inflow to the firm and McLean (2011) argues that cash savings from equity issuance has been increasing over time. Additionally, Huang and Ritter (2016) find that immediate cash needs are an important determinant of equity issues and that firms save $65 \%$ of the proceeds from equity issues in cash at year-end, on average.

We illustrate the importance of operating losses to these patterns by scaling each equity issuer's post-issue cash balances by the magnitude of the company's cash burn rate. ${ }^{2}$ This scaled measure, commonly called "runway" within the venture capital industry, represents an estimate of how many months a firm with negative cash flows can continue to operate at the same rate without an infusion of external capital. Ceteris paribus, equity issuers could increase runway by increasing issuance size and stockpiling cash. However, we find that the median runway after issuance has stayed within the same range for decades, typically between 6 and 18 months, and, most notably, exhibits no time trend over the past two decades, a period during which average cash balances have exploded. In other words, cash savings from issuance have increased substantially, but burn rates have also risen concomitantly. The implication is that firms with high burn rates rapidly deplete their cash balances, but frequently replenish these holdings through private equity

\footnotetext{
${ }^{2}$ We define monthly burn rate as -[Operating CF-Dividends-Capital Expenditures] divided by twelve. For example, a firm that reports negative CF of $\$ 100 \mathrm{MM}$ and capital expenditures of $\$ 20 \mathrm{MM}$ annually has a monthly burn rate of $\$ 10 \mathrm{MM}$. Firms generating positive free cash flows do not have a burn rate.
} 
financings. Indeed, our simulations indicate that within a given calendar year, cash balances of negative operating cash flow equity issuers range between $25 \%$ and $82 \%$ of assets.

Ours is not the first study to document secular decreases in the profitability of U.S. firms. Fama and French (2004) report that the profitability of newly listed firms has become increasingly left-skewed and that, as these firms are integrated into the economy, overall profitability becomes more left-skewed as well. Similarly, Kahle and Stulz (2016) document a decline in average profitability rates among U.S. firms. We extend this literature by (i) showing that the secular trend in profitability is not just a 'new lists' effect; (ii) documenting the increased persistence and magnitude of operating losses; and (iii) linking these trends to secular changes in corporate financial policies.

Other prior studies have investigated financial policies in firms exhibiting losses. For example, DeAngelo, DeAngelo, and Skinner (1992) find that dividend decreases are strongly associated with the presence of losses, particularly if these losses are persistent. Other studies (e.g., Duchin Ozbas, Sensoy (2010) and Campello, Graham, and Harvey (2011)) show that financially weaker firms have difficulties raising capital, particularly in market downturns. In contrast to the troubled firms analyzed in these prior studies, we show that in recent years, firms with persistent operating losses are high-growth firms that are able to frequently raise equity capital.

Our study also contributes to three related strands of the literature. The first seeks to understand the magnitude of cash balances among U.S. firms and why average balances have grown so dramatically in recent years. Our findings complement and extend those from studies that ascribe a role for increased precautionary demands due to uncertainty in future financing needs, and for increased costs of repatriating foreign earnings in explaining high cash balances. 
We show that, in addition to these factors, an increased demand for operational cash to fund immediate, and expected ongoing liquidity needs is an important determinant of observed cash balances. Our findings also provide a potential explanation for the finding in Pinkowitz, Stulz, and Williamson (2016) that differences in average cash balances between U.S. firms and their foreign counterparts are driven by a small set of U.S. firms with very high R\&D expenditures. We show that high cash balances of high R\&D firms are concentrated among those firms with persistent operating losses.

Second, our findings extend the literature on the motives for equity issuance and sources of equity finance. Kim and Weisbach (2008) report that additions to cash holdings are the primary use of equity issue proceeds in a large international sample of IPOs and SEOs, which implies that cash stockpiling is an important motive for equity issuance. DeAngelo, DeAngelo, and Stulz (2010) report that most SEO issuers would have been unable to fund current operating plans in the absence of the equity issue. They thus attribute the issuance decision to the need to fund near-term investment. Our findings indicate that equity issuers in recent years are increasingly characterized by ongoing operating losses and, therefore, high cash burn rates. They not only have immediate funding needs, but also a need to stockpile cash to fund anticipated near-term future funding shortfalls. Nonetheless, this stockpile is of short duration, requiring the firms with persistent operating losses to issue equity far more frequently than has been documented in the prior SEO literature. The issuances are topping up the stockpile on a regular basis, but the firms are burning through the stockpile rapidly. The frequency of issuance is consistent with a staging of capital infusions of the type reported for newly public firms in Hertzel, Huson, and Parrino (2012).

In addition, the predominance of private placements as a source of finance for negative cash flow firms in our data complements prior studies of private investments in public equity 
(PIPEs) that show that PIPEs are more common for firms that are likely to face substantial frictions in the public debt and equity markets. ${ }^{3}$ Our data indicate that such firms are now the typical equity issuer and that more than $90 \%$ of the equity issues of negative cash flow firms in recent years are now private placements. Unlike the PIPEs issuers of prior studies, however, the typical negative cash flow equity issuer in recent years is not a financially troubled firm. They are growing rapidly and exhibit substantial future growth opportunities.

Finally, our findings have implications for the empirical literature that models cash balances as a linear function of firm, country and institutional characteristics. These studies typically include contemporaneous cash flow among the set of variables that capture the firm's sources and uses of funds and, therefore, its operating cash needs. Our findings imply that such models have become increasingly misspecified in recent years as the distribution of firms has shifted towards firms with persistent operating losses. Because these firms exhibit unusually high cash balances, existing models that ignore this nonlinearity systematically underestimate 'normal' cash holdings for firms with persistent negative cash flows.

The rest of the study progresses as follows: Section 2 documents the rise in operating loss firms. Section 3 reports results explaining how the rise in corporate cash holdings is related to operating losses. Section 4 reports results on the relation between operating loss firms and cash savings from equity issuance. Section 5 discusses implications of our findings, and Section 6 concludes.

\footnotetext{
${ }^{3}$ See, for example, e.g. Brophy, Ouimet, and Sialm (2009).
} 


\section{Descriptive evidence on operating losses}

The main sample consists of all U.S firms with total assets greater than \$5 million (in 2016 dollars) between 1970 and 2016. The data are obtained from the Compustat database, Industrial Annual file. Historically regulated firms such as financial firms (SIC codes 6000-6999) and utilities (SIC codes 4900-4999) are excluded, as are firms missing data necessary for the calculation of cash ratios. Within this sample, we identify firm-initiated equity issues such as IPOs, SEOs, and private placements, using the method detailed in McKeon (2015), specifically, those issues in which proceeds from common stock issuance are greater than $3 \%$ of market equity.

We begin by documenting the prevalence of operating losses over time. We define an operating loss as a negative cash flow from operations as reported on the statement of cash flows. Prior to 1987 , firms were not required to report cash flow from operations. When this figure is missing, we calculate an approximation as described in the Appendix. Figure 1 plots the percentage of the sample that reports negative operating cash flows each year since 1960 . The rise is striking. In the early part of the sample, negative operating cash flows are almost non-existent. Despite four recessions between 1960 and 1980 (as defined by the National Bureau of Economic Research (NBER)), the percentage of firms with negative cash flow only exceeds $10 \%$ three times. Since 1990, however, it has rarely been less than $25 \%{ }^{4}$ In 2016, the final year in the sample, nearly $1 / 3$ of the sample firms report negative operating cash flows.

One firm characteristic that has changed substantially over time is R\&D expenditures (Brown et al., 2009). To investigate whether the rise in negative cash flow firms is driven primarily by high $R \& D$ expenditures, we measure OCFRD, which is operating cash flow with $R \& D$ added back. As it turns out, there is more to the story than R\&D. The proportion of firms with negative

\footnotetext{
${ }^{4}$ Kahle and Stulz (2016) also report a decline in average profitability among U.S. firms, but do not investigate its persistence or its connection with corporate financial policies.
} 
OCFRD has also experienced a substantial rise over the same period and by 2016 nearly 1 in 4 firms reports negative operating cash flows even before subtracting $R \& D$ expense.

Figure 1 shows that negative cash flows are pervasive; however, a related question is whether negative cash flows are transitory. We find that it is increasingly the case that firms are experiencing persistent negative cash flows rather than negative cash flows that occur due to a temporary shock. Figure 2 illustrates a strong time trend in the persistence of negative cash flows. Panel A illustrates that in the 1970's and 80's most firms that experienced negative cash flows returned to positive cash flows in the following year. By contrast, less than $1 / 4$ of firms that reported negative cash flow in 2015 followed up with positive cash flow in 2016. Panel B reports the average number of years, including the current year, of consecutive negative cash flows. By construction, the lower bound of 1.0 represents a situation in which every firm reporting negative cash flow in a given year had positive cash flow in the prior year. Consistent with panel A, this measure exhibits a strong time trend, peaking in the last year of the sample at nearly four years. This implies that the occurrence of negative cash flows is not likely to be surprising or unexpected for most firms in recent years. Rather, they are operating with the intention and expectation of extended cash flow deficits. A likely consequence of this expectation is that corporate policies for such firms, such as cash holdings, will be driven at least as much by a plan to manage expected operating deficits as by factors that induce excess holdings such as precaution against the possibility of a negative shock.

The final characteristic to note is that the magnitude of negative cash flow has grown substantially over time. Table 1, panel A reports average CF/assets for the ten deciles during four subperiods: 1970-1979, 1980-1989, 1990-1999, and 2000-2016. All deciles report lower cash flows over time, but within the lowest decile the change is most dramatic. In the 1970's the average 
firm in the lowest decile reported cash flow equal to $-11 \%$ of assets. During the 2000-2016 subperiod, the average was $-58 \%$ of assets. Put another way, firms in this decile burn an average of almost $5 \%$ of assets per month even before accounting for capital expenditures.

Taken together, Figures 1 and 2, and Table 1 highlight three stylized facts about the evolution of firms reporting negative cash flows: Negative cash flows are vastly more prevalent, more persistent, and the magnitude of average negative cash flows within the lowest decile has grown fivefold. Further, Figure 3 charts the distribution of cash flow for two subperiods at the beginning and end of the sample period and reveals that not only has a mass of firms appeared in the left tail in the most recent period, but the density in the center of the distribution has shifted left as well. These findings motivate the inquiry into implications of these transformative shifts in the distribution of cash flows for corporate policy.

In light of the drastic change in the distribution of cash flows, a related question is whether other characteristics of negative cash flow firms have changed. Table 2 reports summary statistics on a variety of firm level variables for firms with negative cash flows. Surprisingly, firm age, measured as number of years as a public firm in Compustat, has increased. The average age of negative cash flow firms in the 1970's is 6.5 years, rising to 11 years in the 2000's. Thus, the shift in the distribution of cash flow is not due simply to the characteristics of newly listed firms. ${ }^{5}$ In terms of size, loss firms have become smaller over time at the median in term of total assets, but larger in terms of market capitalization. It follows that the market-to-book ratio is substantially higher in recent years, averaging 1.16 in the 1970 's versus 2.70 in the 2000 's. Leverage has fallen sharply, whether measured as book or market leverage, and R\&D expenditures as a percentage of assets have increased substantially. Growth patterns have also changed. In the 70's, firms with

\footnotetext{
${ }^{5}$ Fama and French (2004) report that the profitability of newly listed firms has become increasingly left-skewed.
} 
negative cash flows exhibit signs of distress, with declining revenues and declining headcount, on average. In the 1990's and 2000's the opposite is true; negative cash flow firms are growing rapidly on average, both in terms of revenues and employee growth. Finally, payout policies have changed. In the 70 's, negative cash flow firms maintained a dividend yield above $1 \%$ in the year of the loss. By the 2000's, this figure had declined to less than $0.2 \%$. Overall, these statistics suggest that as negative cash flows have become more prevalent, persistent and larger, the characteristics of these firms have changed as well. In recent years, firms with negative cash flows are more commonly highly valued, growth firms.

The industry concentration of negative cash flow firms has also changed over time. In the 2000 's, four industries (Drugs, Business Services, Chips, Medical Eq) account for over $50 \%$ of the observations of negative cash flow. By contrast, the top four industries in the 1970's (Wholesale, Retail, Business Services, Machinery) account for only $26 \%$ of the observations. This is not solely a composition effect whereby the increase is attributable to a rise in the number of firms within industries that are characterized by operating losses. It is also the case that the prevalence of operating losses has increased within every industry. For example, Drugs moved from $9 \%$ of firms reporting losses in the 1970 's to $70 \%$ of firms reporting loses in the 2000 's.

\section{Operating losses and cash holdings}

Numerous studies have documented and offered explanations for the rise of corporate cash holdings over our sample period. ${ }^{6}$ Bates, Kahle, and Stulz (2009) measure the rise in cash holdings

\footnotetext{
${ }^{6}$ Azer et al. (2017) note that cash holdings were also elevated in the 1940's and 1950's and find evidence for carrying cost as an influential determinant. Similalrly, Graham and Leary (2016) document a substantial run-up in cash holdings in the 1930s and 1940s, followed by a decline between 1945 and 1970. They also report that the determinants of cash holdings have changed over time. Because our sample begins in 1970, our study is silent on the the determinant of cash holdings prior to that time.
} 
from 1980 to 2006 and attribute the increase to precautionary motives rather than agency explanations. Specifically, they point to changing firm characteristics including declines in working capital and capital expenditures, and increases in cash flow volatility and R\&D. Younger firms exhibit these characteristics more strongly, and as they enter the economy, the optimal level of cash rises. In Table 2 of their study, they report that the rise in cash holdings for firms with negative earnings has been particularly large.

Table 3 reports that as the prevalence, persistence, and magnitude of negative operating cash flows has increased, cash holdings have grown dramatically. The most dramatic increase in cash balances occur within the lowest deciles of operating cash flow, and the point of divergence in the mid 1980's roughly corresponds with the beginning of the rapid growth of negative cash flow firms in Figure 1. In 1970, cash holdings across the cash flow continuum are similar, and even slightly lower for low cash flow firms. The lowest decile held $7.1 \%$ of assets in cash, while the highest 8 deciles held an average of $8.7 \%$ of assets in cash. During the final year of the sample, 2016 , average cash holdings within the lowest decile has grown to over $65 \%$ of assets, an increase of $822 \%$ over 1970 levels. Cash holdings within the highest eight deciles has also grown, but much more modestly, increasing by $93 \%$ over the sample period. Overall, these figures are consistent with Bates et al. (2009), who document a tripling of cash ratios for negative net income firms over 1980-2006. ${ }^{7}$ The results in Table 3 indicate that the growth has not retreated in the years since 2006. The takeaway is that in order to understand the rise in average cash holdings generally, more attention needs to be paid to the left side of the cash flow distribution where the rise is most evident.

\footnotetext{
${ }^{7}$ In untabulated results, we also measure growth in cash holdings using market assets as the scaling variable. The nominal figures are reduced since negative cash flow firms also have high $\mathrm{M} / \mathrm{B}$ ratios, but the overall relation holds. The growth rate in cash holdings for negative cash flow firms is approximately five times that of positive cash flow firms.
} 
Figure 4 plots the rise in cash holdings. The middle (grey) curve reports the average observed values for the entire sample and shows that average cash holdings have grown by $196 \%$ over the sample period. However, once the sample is split into positive cash flow firms (dotted curve) and negative cash flow firms (bottom black curve), it is clear that negative cash flow firms are responsible for the majority of the overall growth in cash holdings observed within the full sample. If negative cash flow firms are removed from the sample, the growth in cash holdings over 1970-2015 is less than half as large as the growth in cash holdings for the full sample $(90 \%$ vs $196 \%$ increase). The growth in cash balances among negative cash flow firms is a striking $580 \%$.

Three traditional explanations for holding excess cash include repatriation taxes, agency problems, and precautionary motives. ${ }^{8}$ While the uptick in cash holdings for positive cash flow firms could be caused by tax considerations, the massive rise for negative cash flow firms is unlikely to be due to an offshore cash holdup due to repatriation taxes, because (i) they have negative earnings to offset the tax burden, and (ii) only $8.5 \%$ of our sample firms that report operating losses also report foreign income. Similarly, negative cash flow firms exhibit characteristics that would make them less prone to agency problems. In their study of the effect of agency problems on cash holdings, Nikolev and Whited (2014) cite three factors commonly associated with agency concerns: size, perquisite consumption, and limited managerial ownership. Negative cash flow firms are the least susceptible on all three counts. They are, on average, the smallest firms in the economy, they are subject to equity capital raising on a regular basis (as we later show), and are monitored more closely than mature high cash flow firms. Finally, in

\footnotetext{
${ }^{8}$ For evidence on the agency motive, see, for example, Bates, Kahle and Stulz (2009), Harford (1999) and Harford, Mansi, and Maxwell (2013), and Dittmar and Marhrt-Smith (2007). For evidence on the repatriation tax motive, see Foley, Hattzell, Titman, and Twite (2007), Faulkender and Petersen (2012) and Faulkender, Hankins, and Petersen (2017).
} 
untabulated results, we find that negative cash flow firms have the highest levels of managerial ownership.

Although tax motives and agency concerns are mitigated for firms with negative cash flows, precaution remains as a potential explanation for the substantial rise in cash holdings between 1970 and 2016. In recent years, there has been an increased focus on R\&D expenditures in the literature. In addition to the Bates, Kahle, and Stulz (2009) study cited earlier, Falato and Sim (2015) use state-level changes in R\&D tax credits to show that firms increase their cash-toasset ratios when their home state increases R\&D tax credits. Begenau and Palazzo (2016) link the rise in cross-sectional cash holdings with the propensity of newly public firms to hold more cash at entry, particularly those with high R\&D intensity. Pinkowitz, Stulz, and Williamson (2016) find that differences in average cash balances between U.S. firms and their foreign counterparts are driven by a small set of U.S. firms with very high R\&D expenditures,

High R\&D intensity could impact cash holdings through two (not mutually exclusive) mechanisms. First, disrupting R\&D programs is particularly costly (Brown and Peterson, 2011), so the firm may hold extra cash as a precaution. Second, however, many R\&D intensive firms also report negative cash flow. $R \& D$ represents a cash expense that needs to be covered regardless of the fact that it is $\mathrm{R} \& \mathrm{D}$, and resultant cash holdings intended to cover near term operations are more accurately described as a response to the first moment of cash flow rather than the second moment.

To determine whether the operating cash flow effect is simply an overlap with $R \& D$ intensive firms, we analyze R\&D and cash flow jointly in Table 4. Panel A reports the joint distribution by decile for each measure. Not surprisingly, the largest mass is in the lowest cash flow decile and highest R\&D decile, but it only represents $5.8 \%$ of the sample. Extending to the 
three lowest deciles of Cash Flow and the three highest deciles of R\&D only comprises $16.5 \%$ of the sample. Thus, although there is some overlap, it does not appear that the cash flow effect we study is simply a proxy for the R\&D effect studied by others.

Panel B takes a step further to examine cash holdings at high R\&D firms, defined as those within the top two deciles. The results indicate that growth in cash holdings for high R\&D firms is heavily dependent on the firm's cash flow position. Specifically, for high R\&D firms in cash flow deciles 3-10, where cash flow is typically positive, cash holdings have grown an average of 43\%. In contrast, average cash holdings for high R\&D firms in the lowest cash flow decile have grown $744 \%$.

Figure 5 plots the relation between cash holdings and operating cash flow levels in each of four subperiods. Similar to Figure 4, the most striking increase is observed within firms at the low end of cash flow. However, Figure 5 reveals a more interesting observation, which is that the relation between cash holdings and cash flow has become increasingly nonlinear over time. Standard models of cash holdings, in which cash is specified as a linear function of cash flow (and other characteristics), obscure this effect. Misspecification due to incorrect functional form of the cash flow variable results in systematic prediction error. We discuss these implications in greater detail in Section 5.

While the relation between cash holdings and cash flow was roughly flat in the 1970's, each subsequent decade has increased in convexity. Thus, it is not the case that the increase in cash holdings in the time series is driven exclusively by the increasing prevalence and magnitude of negative earnings; the persistence is also important. For any given level of cash flow to the left of zero, the median firm in the 2000s holds more cash than does the median firm in the 1990 s, which holds more than the median firm in the 1980s. What has changed over time is the duration 
of the negative cash flows. A firm reporting negative cash flow in 1970 is expecting to revert to positive cash flows soon while a firm in the 2000s reporting the very same level of negative cash flow is more likely to be expecting that level to persist for an extended period of uncertain duration. This creates an additional precautionary demand for cash.

We conclude this section by examining the association between cash holdings and cash flow realizations prior to, and subsequent to, the first year in which a firm reports negative cash flow. This analysis is motivated by the DeAngelo, DeAngelo and Skinner (1992) finding that dividend policies upon the realization of negative earnings respond to the future persistence of negative earnings. We hypothesize that cash policies are similarly responsive to the firm's expectation about the persistence of negative cash flows.

Table 5 reports median cash holdings for four subgroups based on the persistence of future negative cash flows and history of previous cash flows. The Persistent category consists of firms that are entering a run of negative cash flow that is at least three years in duration. The Transitory subgroup is made up of firms that return to positive cash flow the following year. New Firms are those that are less than three years old. Fallen Angels are firms that reported at least five years of positive cash flow before entering the negative cash flow sample.

The results in Table 5 indicate that firms behave as if they have some foresight about the persistence of negative cash flows. We find that in recent years, firms entering a run of persistently negative cash flow realizations hold substantially more cash than firms experiencing a transitory negative cash flow shock. This is true not only for new firms, but also those that have previously reported a long stretch of positive cash flows. These results are consistent with the notion that the persistence of the negative cash flows matters for corporate policies and that firms can forecast persistence ex ante. 


\section{Operating losses and external financing patterns}

Our evidence indicates that firms with persistent operating losses build large cash balances to fund these losses. However, it is unclear how they amass such large cash holdings. Although firms with persistent losses exhibit large and ongoing liquidity needs, they are also likely to face large frictions in the market for external funds. The uncertainty as to the duration of losses, coupled with the possibility of information asymmetry raises the potential for agency problems if the firm raises a substantial amount of funds in the capital market. These concerns are common in the venture capital market and the literature identifies the staging of financing as one way to mitigate financing frictions in venture capital funded firms [see, for example, Gompers (1995)]. Hertzel, Huson, and Parrino (2012) extend this logic to newly public firms and find evidence consistent with staging in the timing and size of equity financing in IPO and initial follow-on equity offerings. Such staging, however, can also be costly in that it forces firms to incur additional issuance costs. In this section, we investigate the sources of external finance in our sample firms and analyze the extent to which financing patterns have evolved as firms have increasingly become characterized by persistent operating losses. In particular, we explore the extent to which the financing of firms are consistent with the staging of capital infusions.

\subsection{Sources of external finance}

In Table 6, we investigate three mechanisms that firms can utilize to generate cash: equity issues, debt issues, and the sale of fixed assets. We measure each of these sources, scaled by total assets, and compare the average values within each cash flow decile at the beginning of the sample and the end of the sample. 
In the 1970's, low cash flow firms raised little equity relative to high cash flow firms. On average, a firm in the highest decile of cash flow raised over four times as much equity as a percentage of assets compared to a firm in the lowest cash flow decile. For debt, the story is different. Firms in all cash flow deciles other than the highest raised more debt than equity on average. Additionally, sale of fixed assets appears to be an important source of cash in the 70's for firms with very low cash flow, constituting a larger source of capital than either debt or equity.

Almost the exact opposite is true in recent years. Over the past decade, low cash flow firms raise far more cash through equity than through either debt issues or the sale of fixed assets. Relative to assets, equity issues raise, on average, 17 times the proceeds of debt issues and 178 times the proceeds from the sale of fixed assets in the lowest decile of cash flow. Meanwhile, firms in the highest cash flow decile are now repurchasing both debt and equity, on average. As shown in Table 2, these stylized facts have had a marked impact on capital structure for negative cash flow firms.

\subsection{Staging in debt financing through debt maturity structure}

Although the staging of capital infusions is typically associated with the equity market, Hertzel, Huson, and Parrino (2012) note that the use of short maturities in debt financing can also be viewed as a form of staged financing. Companies with short maturity debt are forced to renegotiate with creditors to roll over existing debt claims, thereby offering creditors the ability to adjust the terms of debt contracts based on perceptions of company performance and growth opportunities.

In Figure 6, we plot the median percentage of debt maturing in more than three years for our sample companies. Consistent with the findings in Custodio et al. (2013), we find that debt 
maturity significantly declines from the 1970 's to 2008 . When we split the sample into positive and negative cash flow firms, we find that the percentage of debt maturing in more than three years is always substantially less for negative cash flow firms than for positive cash flow firms. In fact, since 1997, the median negative cash flow firm has no debt maturing in more than three years. Interestingly, although median debt maturity has increased markedly for positive cash flow firms since 2008 , the median percentage of debt maturing in greater than three years remains at $0 \%$ for negative cash flow firms. These findings are consistent with negative cash flow firms using short maturities to stage debt infusions. Moreover, our findings imply that a large portion (though not all) of the systematic decrease in debt maturity documented in Custodio et al. (2013) is associated with the increasing proportion of firms exhibiting negative cash flow.

\subsection{Staging in equity financing}

Figure 7 illustrates that over the same time period as the rise in cash holdings and overall prevalence of operating loss firms, the characteristics of equity issuers have changed, particularly with regards to cash flow. In the 1970's and 1980's, firms issuing equity are cash flow positive on average, but in every year since 1989 , the average equity issuer is burning cash. These results are consistent with anecdotal evidence suggesting that it has become easier for negative cash flow firms to raise equity capital in recent years and with the evidence in Fama and French (2004) showing that earnings become progressively left skewed through time for newly listed firms. ${ }^{9}$

To further analyze the relation between cash flow and equity issuance frequencies, we calculate the mean number of firm-initiated issuances per year for each cash flow decile based on

\footnotetext{
${ }^{9}$ For example, Jay Ritter notes that "In the early Eighties, the major underwriters insisted on three years of profitability. Then it was one year, then it was a quarter. By the time of the Internet bubble, they were not even requiring profitability in the foreseeable future." (Rolling Stone, April 5, 2010).
} 
quarterly data. Table 7 reports the results of this analysis. While Figure 7 suggests that a large portion of equity issuances are conducted by low cash flow firms, Table 7 demonstrates the inverse: a large portion of low cash flow firms are equity issuers. In fact, between 2010 and 2016 the lowest decile of cash flow recorded 0.93 firm-initiated issuances per firm per year.

In addition to variation in issue frequencies, positive and negative cash flow firms also differ in their choice of equity issuance mechanisms. Table 8 reports the proportion of firminitiated equity issues that are issued to the public via an SEO versus issued through a private placement. ${ }^{10}$ Both positive and negative cash flow firms exhibit a positive trend in the use of private placements over time, but for negative cash flows firms this mechanism makes up the vast majority of equity issues. Over the last five years for which we have data (2009-2013), private placements comprise over $88 \%$ of all issues in every year for negative cash flow firms, rising as high as $93 \%$ in 2011. In addition, we find in untabulated results that of the few SEOs issued to the public by negative cash flow firms, the majority are shelf offerings.

The combination of increased issuance frequency and increased rate of private placements among negative cash flow firms is consistent with the view that negative cash flow firms face substantial frictions in the equity issuance market. These frictions are potentially mitigated by a staging of capital infusions much like what is observed for private firms receiving venture capital financing. Consistent with this notion, we find that $60 \%$ of the private placements for which we have investor identities are characterized by a repeat investor. ${ }^{11}$

\footnotetext{
${ }^{10}$ We categorize Confidentially Marketed Public Offerings (CMPOs) as "Private" as they are closer in nature to private placements than to traditional SEOs.

${ }^{11}$ In a related study of newly-public firms, Iliev and Lowry (2017) report that $13 \%$ of such firms raise equity capital from venture capitalists in the first three years following an initial public offering. They argue that venture capitalists have a comparative advantage in overcoming frictions in the equity issuance market.
} 
Frequent equity issues are puzzling in the presence of large fixed issuance costs in the market for seasoned equity offerings. Our evidence suggests, however, that the staging of equity capital infusions is increasingly done through the private placement mechanism in which fixed issuance costs are much lower. In untabulated results, we find that firms issuing privately are smaller and that cash flow is more negative compared with the firms issuing publicly, consistent with traits that lead to higher issuance costs. Additionally, we find that private investment rounds are comparatively smaller; these firms have an average of 12 months of runway following financing events, as compared with 23 months for public issuers.

\subsection{Equity issuance, cash savings, and runway}

Kim and Weisbach (2008) report that a large fraction of equity issues is saved as cash and several studies link this savings behavior to precautionary motives. ${ }^{12}$ That is, firms issue equity and stockpile a portion of the issue proceeds for future use. To investigate the size of the cash stockpile relative to the needs of the firm, we borrow a metric from the venture capital industry, where negative cash flows for portfolio firms are commonplace. Within venture-backed firms, a figure that often underlies decisions about cash holdings and equity issuance is the monthly "burn rate," which we define as operating cash flow minus dividends and capital expenditures, divided by 12 . Table 9 reports the median burn rate as a percentage of total assets over time for equity issuers with negative cash flow. It is monotonically increasing, rising from about $8 \%$ in the 1970's to over $25 \%$ in the most recent period. In the 1970 's, the median level of cash holdings for negative cash flow equity issuers was less than 5\% of assets at year end. At 2016 burn rates, a stockpile of that size would be depleted before the end of March.

\footnotetext{
${ }^{12}$ See, for example, McLean (2011), Bolton, Chen and Wang (2012), Warusawitharan and Whited (2016), Eisfeldt and Muit (2016), Huang and Ritter (2016), McLean and Palazzo (2016), and McLean and Zhao (2017)..
} 
Cash holdings divided by the monthly burn rate is referred to as "runway," or in other words, how many months a company could sustain current operations without an infusion of external capital. Investors can limit runway by staging investment to mitigate overinvestment problems. Hertzel et al. (2012) find that public market staging is particularly strong for firms with high R\&D and intangible assets. Additionally, they report that the median length of time before returning to the capital market is 12 months. We extend their findings by analyzing runway length over time to detect whether it has changed in ways similar to average cash holdings.

Figure 8 plots the median runway at the time of issuance for negative operating cash flow firms over the sample period. In the early portion of the sample when operating losses were rare, runways for operating loss firms were shorter, typically around 6 months. Beginning in the late 1980 's, twelve months of runway is more typical and the chart shows that it has remained between 6 and 18 months for the last 30 years. (We scale the chart by 48 months since this is the median duration of losses at the end of the same period.) We also note that many other firm characteristics have changed, such as those associated with precautionary cash balances (e.g., R\&D intensity and cash flow volatility), but these factors have not altered the median runway of equity issuers in meaningful ways. For negative cash flow firms, having about a year's supply of cash is the norm. These firms aren't saving more relative to their needs; but their operational needs have grown substantially.

The picture that emerges from these findings is one in which firms with high burn rates rapidly deplete their cash balances, but frequently replenish these holdings through private equity financings. In fact, in our data, annual burn rates and annual equity issuance are nearly identical for this set of firms. This implies large intra-year variation in cash balances for firms with high burn rates. Note, however, that such variation is unobservable to the econometrician analyzing 
annual data. In Figure 9, therefore, we present simulated cash holdings for such a firm over a 24 month period. We calibrate the values on cash holdings, burn rates, and equity issuance to the average observed values for firms in the highest decile of cash holdings that issued equity during 2007-2016. As illustrated in Figure 9, year-end cash balances are relatively stable; however, within the year, cash balances fluctuate between $25 \%$ and $82 \%$ of assets as burn rates deplete reserves and equity issues replenish them. What emerges is a saw-toothed pattern to cash holdings within individual firms over time.

Such a pattern complements the precautionary motives for savings out of equity issuance analyzed in prior studies. ${ }^{13}$ These studies predict that firms are likely to issue and save when stock prices are high in order to have cash available for future periods in which external finance is costly. Such considerations undoubtedly affect the timing of equity issues in our data and the time-series variation in the median post-issue runway that we report in Figure 8. In addition to these timing considerations, however, our findings indicate that in recent years, the near-term operating needs of firms issuing equity has become a first-order driver of issuance behavior and that such needs are a predominant factor in explaining the time-series of cash balances.

\section{Implications for models of cash holdings}

Nonlinearity in the association between cash holdings and cash flow implies that models of cash holdings that estimate such holdings as a linear function of cash flow are increasingly misspecified. One econometric option to deal with convexity is to add a squared term to the specification. However, as was shown in Figure 5, it is primarily nonlinearity on the left side of the cash flow distribution that is the focus of this study. For this reason, we employ an indicator

\footnotetext{
${ }^{13}$ See the studies cited in footnote $\# 9$.
} 
for negative values of cash flow, and an interaction term between this indicator and the value of cash flow/assets to capture the magnitude of the losses. These variables allow for inference of differential effects for negative and positive cash flow firms.

Table 10 reports results from OLS regressions of cash holdings on standard determinants used in the literature (equation 1) plus the new variables we describe above to capture the effects of negative cash flow on cash policy (equation 2). Specifically,

$$
\begin{aligned}
& {\frac{\operatorname{Cash}}{\operatorname{Assets}_{i, j, t}}}_{i=\beta_{1}}{\frac{C F}{\operatorname{Assets}_{i, t}}}+\beta_{2} \ln (M E)_{i, t}+\beta_{3} \overline{\operatorname{CFVol}}_{j, t}
\end{aligned}
$$

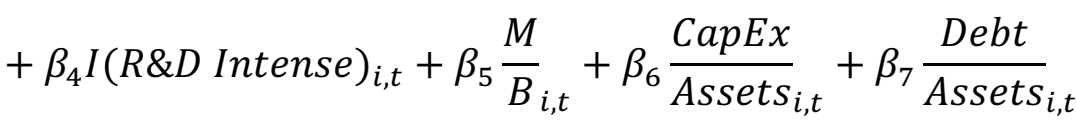

$$
\begin{aligned}
& +\beta_{8} I(\text { Dividend })_{i, t}+\varepsilon_{i, t}
\end{aligned}
$$

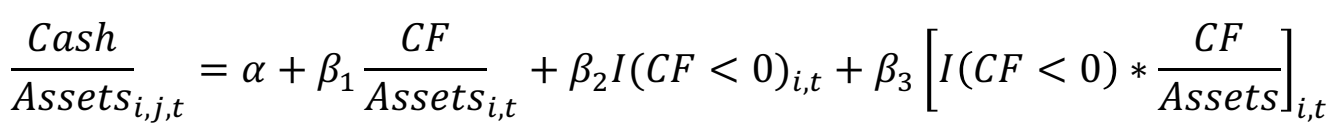

$$
\begin{aligned}
& +\beta_{4} \ln (M E)_{i, t}+\beta_{5} \overline{C F V o l}_{j, t}+\beta_{6} I(R \& D \text { Intense })_{i, t}+\beta_{7} \frac{M}{B_{i, t}}
\end{aligned}
$$

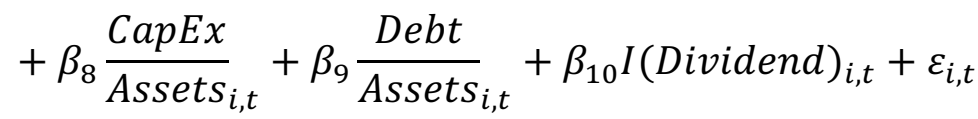

Both specifications control for traditional factors related to the precautionary demand for cash. Specifically, we include Size to capture financing constraints, Industry Cash Flow Volatility to capture probability of a negative shock to cash flow, an indicator of high $R \& D$ intensity and market-to-book ratio, both of which are related to growth opportunities. To isolate the effect of precaution related to $R \& D$ from the cash flow effect of $R \& D$, we control for the existence of an R\&D intensive investment agenda, but not the level of $R \& D$, which is an operating expense. 
In column 1 of Table 10, Cash Flow carries a large negative coefficient, consistent with several prior studies, but challenging to interpret in light of the nonlinearity between cash flow and cash. Column 2 reveals the importance of including variables that capture operating needs. Both the negative earnings indicator and the interaction term are highly significant determinants of corporate cash holdings. Moreover, after controlling for operating losses, the coefficient on Cash Flow reverses and is highly significant in the opposite direction. One implication is that the model with the negative earnings variables should also improve model fit on the right side of the cash flow distribution, where large positive cash flows are otherwise penalized in predictions of cash holdings if cash flow is forced into a linear specification where it carries a negative coefficient.

Columns 3 and 4 add year fixed effects to the models and columns 5 and 6 add year and industry fixed effects. Neither fixed effects specification picks up the impact of negative cash flow firms. Columns 7 and 8 report Fama-MacBeth regressions with similar results. In both the fixed effects models as well as the Fama-MacBeth models, the sign of the coefficient on Cash Flow in the linear specification is negative and significant, whereas the specification with indicators for negative cash flow flips the sign on the Cash Flow variable. These findings imply that the relation between cash flow and cash holdings depends greatly on the sign of the cash flows.

In Figures $10 \mathrm{~A}$ and $10 \mathrm{~B}$, we detail the effects of functional form misspecification on prediction error. Figure 10A compares average prediction error within each decile in the full sample panel regressions. The comparison is between the standard model and the model that captures nonlinearity by adding the negative indicator and interaction term as in (2). The improvement is most evident in the tails of the distribution, which is not surprising due to the convex relation. Overall, improvement is noted in seven of the ten deciles. These results are 
consistent with the finding in Table 10 that the linear specification does not do a good job of characterizing the relation between cash and cash flow.

Figure 10B compares three prediction models designed to account for time varying changes in cash holdings. The first is the standard model with year fixed effects added, the second adds both year and industry fixed effects. The third is the nonlinear model estimated in annual crosssections for each year of the sample to allow the coefficients to vary through time, similar to the technique used in Harford et al. (2009) to predict leverage targets.

Both fixed effects models create larger prediction errors in most deciles, again particularly in the tails. In the case of year fixed effects, the annual cross sections perform better in eight of the 10 deciles, and when compared to the model with year and industry fixed effects the annual cross sections perform better in every decile but one. The reason is intuitive: the lion's share of the increase in cash holdings has occurred in the tails of cash flow, but year fixed effects impact the predicted value uniformly across the distribution.

Finally, in Table 11, we use the augmented cash holdings model to provide a 'back of the envelope' estimate of the relative contribution of cash flow levels versus cash flow volatility to predicted cash holdings for negative cash flow firms. The first two columns report coefficients from estimating Equation (2) over five-year subperiods at the beginning (1970-1974) and end (2011-2015) of the sample period: The third and fourth columns report the subperiod median values of each variable for firms that report negative operating cash flow. The predicted contribution to cash holdings, reported in the final two columns, is the product of the coefficients and median observed values.

The effect of cash flow levels on predicted cash holdings is revealed by the cash flow variables. In this example, the level variables contribute nearly twice as much to the increase in 
predicted cash as the volatility variable. $27 \%$ of the increase in predicted cash/assets is attributable to cash flow levels, while $15 \%$ of the increase is attributable to cash flow volatility.

\section{Conclusion}

The population of U.S. firms is increasingly comprised of firms with persistent, large negative cash flows. Such characteristics create ongoing liquidity needs that are directly tied to current and near-term operations. Correspondingly, we find that cash balances have increased much more substantially in recent decades for these firms than for the rest of the population. Perhaps most strikingly, we find that over the past four decades, average cash holdings have risen by over $580 \%$ for firms with negative cash flow, as compared with $90 \%$ for firms with positive cash flow. Our evidence thus supports the view that the recent growth in cash balances among U.S. firms is not solely a reflection of increased precautionary demands due to cash flow volatility, increased disincentives to repatriate foreign earnings, or increased agency problems. Rather, for an increasing proportion of firms, higher cash balances reflect additional precautionary demand due to near-term operational needs and an expectation of future negative cash flows for an uncertain duration.

Additionally, we find that equity issuance activity is increasingly dominated by firms with negative cash flows. Although firms are saving a substantial proportion of equity issuance proceeds in cash, they are also burning cash at an unprecedented rate. As a result, there is virtually no time trend in estimates of cash runway over the last 25 years. Moreover, since 2000, firms with negative operating cash flows issue equity almost once every year and appear to mitigate the large fixed costs of SEOs by primarily raising equity through private placements. Such behavior is 
consistent with a supply-driven public market staging of finance of the type studied in Hertzel et al. (2012).

Our study is silent on the underlying forces that drive the increase in the proportion of public firms with persistent operating losses. We conjecture that there are two broad categories of explanation, which are not mutually exclusive. First, the time-series shift could be due to specific financial innovations that have made it easier for early stage, unprofitable firms to obtain public financing. For example, the rise of venture capital beginning in the 1980's is associated with an expansion in early-stage funding for firms with negative earnings. It is possible that we are simply observing spillover into the public markets from VC-backed firms. We note, however, that the dearth of IPOs in recent years suggests that this is unlikely to be a complete explanation.

Second, the trend towards a greater number of firms with persistent losses could be driven by a shift in the underlying economics of new economy firms, particularly with regards to growth patterns. Historically, firms grew linearly with investment. Investments in property, plant, and equipment converted to sales relatively quickly. Today, investment more often takes the form of R\&D, organizational capital, and other types of intangibles. There can be a long lag between investment in intangibles and resultant sales; however, intangible assets can scale in ways that tangible assets cannot. Growth can be quite rapid many years after the investment. The result is convexity in the relation between sales and investment. One consequence of this is that it may appear that investment is less responsive to $\mathrm{Q}$ in the time series, but this could simply be a function of the challenges inherent in measuring intangible investment. We leave these topics to future research. 


\section{References}

Azer, J., Kagy, J., and Schmalz, M.C., 2016, Can Changes in the Cost of Carry Explain the Dynamics of Corporate 'Cash' Holdings?, Review of Financial Studies, doi: 10.1093/rfs/hhw021.

Bates, T. W., Kahle, K. M., \& Stulz, R. M. 2009. Why do US firms hold so much more cash than they used to?. The Journal of Finance 64, 1985-2021.

Begenau, J., \& Palazzo, B. 2015. Firm Selection and Corporate Cash Holdings. Working Paper.

Bolton, P., H. Chen, and N. Wang, 2013, Market timing, investment, and risk management, Journal of Financial Economics, 109, 40-62.

Brophy, D.J., P.P. Ouimet, and C. Sialm, 2009, Hedge funds as investors of last resort? Review of Financial Studies 22, 541-574.

Brown, J. R., Fazzari, S. M., \& Petersen, B. C. 2009. Financing innovation and growth: Cash flow, external equity, and the 1990s R\&D boom. The Journal of Finance 64, 151-185.

Brown, J. R., \& Petersen, B. C. 2011. Cash holdings and R\&D smoothing. Journal of Corporate Finance 17, 694-709.

Campello, M., J. Graham, and C. Harvey, 2010, The real effects of financial constraints: Evidence from a financial crisis, Journal of Financial Economics 97, 470-487

Custodio, C., Ferreira, M.A., and Laureano, L. 2013. Why are US firms using more short-term debt? Ournal of Financial Economics 108, 182-212.

DeAngelo, H., DeAngelo, L., and Skinner, D. J. 1992. Dividends and losses. The Journal of Finance 47, 1837-1863.

DeAngelo, H., DeAngelo, L. and Skinner, D.J., 2004. Are dividends disappearing? Dividend concentration and the consolidation of earnings. Journal of Financial Economics 72, 425456.

DeAngelo, H., DeAngelo, L., \& Stulz, R. M. 2010. Seasoned equity offerings, market timing, and the corporate lifecycle. Journal of Financial Economics 95, 275-295.

Dittmar, A., and J. Mahrt-Smith, 2007, Corporate governance and the value of cash holdings, Journal of Financial Economics 83, 599-634.

Duchin, R. (2010). Cash holdings and corporate diversification. The Journal of Finance 65, 955992.

Duchin, R., O. Ozbas, and B. Sensoy, 2010, Costly external finance, corporate investment, and the subprime mortgage crisis, Journal of Financial Economics 97, 418-435.

Duchin, R., Gilbert, T., Harford, J., \& Hrdlicka, C. M. 2015. Precautionary savings with risky assets: When cash is not cash. Working paper, University of Washington. 
Eisfeldt, A., and T. Muir, 2016, Aggregate external financing and savings waves, Journal of Monetary Economics, forthcoming.

Falato, A., Kadyrzhanova, D., \& Sim, J. 2013. Rising intangible capital, shrinking debt capacity, and the US corporate savings glut. Working paper.

Falato, A., \& Sim, J. 2014. Why do innovative firms hold so much cash? Evidence from changes in state $R \& D$ tax credits. Working paper.

Fama, E.F., and French, K.R., 2004, New lists: Fundamentals and survival rates, Journal of Financial Economics 73, 229-269.

Faulkender, M.W. and M. A. Petersen, 2012, Investment and Capital Constraints: Repatriations under the American Jobs Creation Act, Review of Financial Studies, 25, 3351-3388.

Faulkender, M.W., K. Hankins, and M. Petersen, 2017, Understanding precautionary cash at home and abroad, Working Paper.

Foley, C. F., Hartzell, J. C., Titman, S., \& Twite, G. 2007. Why do firms hold so much cash? A tax-based explanation. Journal of Financial Economics 86, 579-607.

Fresard, L. (2010). Financial strength and product market behavior: The real effects of corporate cash holdings. The Journal of Finance 65, 1097-1122.

Gompers, P. (1995). Optimal investment monitoring and the staging of venture capital. The Journal of Finance 50, 1461-1490.

Graham, J.R. and Leary, M.T., 2016, The Evolution of Corporate Cash, Working Paper, National Bureau of Economic Research.

Han, Seungjin, and Jiaping Qiu, 2007, Corporate precautionary cash holdings, Journal of Corporate Finance 13, 43-57.

Harford, J., 1999, Corporate cash reserves and acquisitions, Journal of Finance 54, 1969-1997.

Harford, J., S. Mansi, and W. Maxwell, 2008, Corporate governance and firm cash holdings, Journal of Financial Economics 87, 535-555.

Harford, J., Klasa, S., \& Maxwell, W. F. 2014. Refinancing risk and cash holdings. The Journal of Finance, 69(3), 975-1012.

Harford, J., Klasa, S., \& Walcott, N. 2009. Do firms have leverage targets? Evidence from acquisitions. Journal of Financial Economics, 93, 1-14.

Harford, Jarrad, Sattar Mansi, and William Maxwell, 2008, Corporate governance and firm cash holdings in the U.S., Journal of Financial Economics 87, 535-555.

Hertzel, M. G., Huson, M. R., \& Parrino, R. 2012. Public market staging: The timing of capital infusions in newly public firms. Journal of Financial Economics 106, 72-90. 
Huang, R., and J. R. Ritter, 2016, Corporate cash shortfalls and financing decisions. Working paper.

Iliev, P. and M. Lowry, 2017, Venturing beyond the IPO: Venture capitalists' investments in newly public firms, Working Paper.

Kahle, K. and R. M. Stulz, 2016, Is the American public corporation in trouble? Working Paper, Ohio State University.

Keynes, John Maynard, 1936, The General Theory of Employment, Interest and Money (Harcourt Brace, London).

Klasa, S., Maxwell, W. F., \& Ortiz-Molina, H. 2009. The strategic use of corporate cash holdings in collective bargaining with labor unions. Journal of Financial Economics 92, 421-442.

Kim, W., \& Weisbach, M. S. 2008. Motivations for public equity offers: An international perspective. Journal of Financial Economics 87, 281-307.

Lins, K. V., Servaes, H., \& Tufano, P., 2010. What drives corporate liquidity? An international survey of cash holdings and lines of credit. Journal of Financial Economics 98, 160-176.

McKeon, S.B., 2015. Employee Option Exercise and Equity Issuance Motives. SSRN Working paper.

McLean, R. D., 2011. Share issuance and cash savings. Journal of Financial Economics 99, 693715.

McLean, R. D., Palazzo, B., 2016, Precautionary finance: Evidence from the timing and size of debt and equity issues. Working paper.

McLean, R. D., and M. Zhao, 2017, Cash savings and capital markets, working paper, Georgetown University and Securities and Exchange Commission.

Nikolov, B. and T. Whited, 2014, Agency conflicts and cash: Estimates from a dynamic model, Journal of Finance 69, 1883-1921.

Opler, Tim, Lee Pinkowitz, Rene Stulz, and Rohan Williamson, 1999, The determinants and implications of corporate cash holdings, Journal of Financial Economics 52, 3-46.

Pinkowitz, L., Stulz, R.M., and R. Williamson, 2016, Do U.S. firms hold more cash than foreign firms? Review of Financial Studies 29, 309-348.

Walker, M. D., Wu, Q., \& Zhao, J. 2015. SEOs When in Distress. Working paper.

Warusawitharana, M. and T. Whited, 2015, Equity Market Misvaluation, financing, and investment, Review of Financial Studies 29, 603-654. 


\section{Appendix A: Variable Descriptions}

\begin{tabular}{|c|c|}
\hline Cash Holdings & $\mathrm{CHE} / \mathrm{AT}$ \\
\hline EBITDA & EBITDA/AT \\
\hline EBITDARD & [EBITDA+XRD]/AT. XRD is coded to 0 if missing. \\
\hline \multirow{3}{*}{ Operating Cash Flow } & OANCF. \\
\hline & If missing, replaced by \\
\hline & $\mathrm{NI}+\mathrm{DPC}+\mathrm{TXDC}+\mathrm{ESUBC}+\mathrm{SPPIV}+\mathrm{FOPO}+\mathrm{FSRCO}+\mathrm{WCAPC}+\mathrm{APALCH}+\mathrm{INVCH}+\mathrm{RECCH}$ \\
\hline $\mathrm{I}(\mathrm{CF}<0)$ & Indicator that takes a value of 1 when Cash Flow $<0$, and 0 otherwise \\
\hline Cash Flow x I $(\mathrm{CF}<0)$ & Interaction that takes the value of Cash Flow when Cash Flow $<0$, and 0 otherwise \\
\hline Size & Natural Log of AT \\
\hline Industry CF Vol & $\begin{array}{l}\text { Standard deviation of cash flows is measured for each firm over up to } 10 \text { years (minimum 3). Values } \\
\text { are averaged based on Fama French } 48 \text { industries annually. }\end{array}$ \\
\hline $\mathrm{R} \& \mathrm{D}$ & $\mathrm{XRD}$. Coded to 0 if missing. \\
\hline $\mathrm{I}(\mathrm{R} \& \mathrm{D}$ Intense $)$ & Indicator that takes a value of 1 when $[\mathrm{XRD} / \mathrm{AT}]>0.02$, and 0 otherwise \\
\hline $\mathrm{M} / \mathrm{B}$ & $(\mathrm{AT}+\mathrm{MKTVAL}-\mathrm{SEQ}) / \mathrm{AT}$. MKTVAL is replaced by CSHO*PRCC $\mathrm{C}$ if missing. \\
\hline Capital Expenditures & CAPX. Coded to 0 if missing. \\
\hline Leverage (Book) & {$[\mathrm{DLTT}+\mathrm{DLC}] / \mathrm{AT}$} \\
\hline Leverage (Market) & {$[\mathrm{DLTT}+\mathrm{DLC}] /(\mathrm{AT}-\mathrm{SEQ}+\mathrm{MKVALT})$} \\
\hline Revenue Growth & {$\left[\mathrm{REV}_{\mathrm{t}}-\mathrm{REV}_{\mathrm{t}-1}\right] / \mathrm{REV}_{\mathrm{t}-1}$} \\
\hline Employee Growth & {$\left[\mathrm{EMP}_{\mathrm{t}}-\mathrm{EMP}_{\mathrm{t}-1}\right] / \mathrm{EMP}_{\mathrm{t}-1}$} \\
\hline Dividend Yield & DVC/MKVALT \\
\hline \multicolumn{2}{|l|}{ Firm-initiated } \\
\hline Equity Issuance & SSTK when [SSTK/MKTVAL] $>0.03$ \\
\hline Net Equity Issuance & SSTK-PRSTK \\
\hline Net Debt Issuance & {$[\mathrm{DLTT}+\mathrm{DLC}]_{\mathrm{t}}-[\mathrm{DLTT}+\mathrm{DLC}]_{\mathrm{t}-1}$} \\
\hline Burn Rate & -[Operating Cash Flow-DVC-CAPX]. Divided by 12 for monthly burn rate. \\
\hline Runway & CHE/Monthly Burn Rate \\
\hline
\end{tabular}

All variable mnemonics are from Compustat, Industrial Annual File

All ratios are winsorized at the 1st and 99th percentiles. 


\section{Table 1}

\section{Evolution of cash flow by decile}

This table reports mean values of $\mathrm{CF} /$ assets for deciles formed annually. The full sample is 188,368 firm year observations over the period 1970-2016. Values are averaged over all firm year observations within the decile during the specified subperiod.

\begin{tabular}{ccccc}
$\begin{array}{c}\text { CF } \\
\text { decile }\end{array}$ & $1970-79$ & $1980-89$ & $1990-99$ & $2000-16$ \\
\hline 1 & $(0.11)$ & $(0.36)$ & $(0.43)$ & $(0.58)$ \\
2 & 0.04 & $(0.05)$ & $(0.12)$ & $(0.15)$ \\
3 & 0.07 & 0.03 & $(0.03)$ & $(0.03)$ \\
4 & 0.10 & 0.07 & 0.01 & 0.02 \\
5 & 0.12 & 0.10 & 0.04 & 0.05 \\
6 & 0.14 & 0.13 & 0.07 & 0.07 \\
7 & 0.17 & 0.16 & 0.09 & 0.10 \\
8 & 0.19 & 0.20 & 0.12 & 0.12 \\
9 & 0.24 & 0.26 & 0.16 & 0.16 \\
10 & 0.36 & 0.45 & 0.24 & 0.25
\end{tabular}




\section{Table 2}

\section{Summary statistics for negative cas h flow firms}

This table reports mean (median) values for firms with negative cash flow. All variables are defined in the appendix. The full sample is 188,368 firm year observations over the period 1970-2016.

\begin{tabular}{lrrrr} 
& \multicolumn{1}{c}{1970 's } & 1980 's & 1990 's & 2000 's \\
\cline { 2 - 5 } $\mathrm{N}$ & 2,846 & 8,290 & 15,862 & 20,285 \\
Firm Age & 6.5 & 7.7 & 7.7 & 11.0 \\
Total Assets (2016\$) & 6 & 5 & 5 & 8 \\
& 436 & 276 & 250 & 485 \\
Mkt Cap (2016\$) & 110 & 33 & 42 & 54 \\
& 104 & 119 & 292 & 388 \\
M/B & 33 & 25 & 56 & 70 \\
& 1.16 & 1.87 & 2.73 & 2.70 \\
Book Leverage & 0.92 & 1.23 & 1.73 & 1.71 \\
& 0.386 & 0.347 & 0.248 & 0.225 \\
Mkt Leverage & 0.382 & 0.327 & 0.180 & 0.095 \\
& 0.387 & 0.273 & 0.170 & 0.139 \\
R\&D/TA & 0.403 & 0.245 & 0.093 & 0.046 \\
& 0.015 & 0.041 & 0.092 & 0.150 \\
Revenue Growth & 0.000 & 0.000 & 0.007 & 0.063 \\
& $-1.7 \%$ & $16.1 \%$ & $35.0 \%$ & $28.9 \%$ \\
Employee Growth & $-3.8 \%$ & $-1.2 \%$ & $10.4 \%$ & $2.8 \%$ \\
& $-5.7 \%$ & $0.6 \%$ & $18.7 \%$ & $7.5 \%$ \\
Dividend Yield & $-6.7 \%$ & $-4.5 \%$ & $5.3 \%$ & $0.0 \%$ \\
& $1.07 \%$ & $0.47 \%$ & $0.20 \%$ & $0.17 \%$ \\
& $0.0 \%$ & $0.0 \%$ & $0.0 \%$ & $0.0 \%$
\end{tabular}


Table 3

Evolution of ave rage cash holdings by cash flow decile

This table reports mean values of cash/assets for cash flow deciles formed annually. The full sample is 188,368 firm year observations over the period 1970-2016. Values are averaged over all firm year observations within each decile each year.

\begin{tabular}{|c|c|c|c|}
\hline & \multicolumn{3}{|c|}{ Deciles } \\
\hline & 1 & 2 & $3-10$ \\
\hline 1970 & 0.071 & 0.061 & 0.087 \\
\hline 1971 & 0.076 & 0.074 & 0.096 \\
\hline 1972 & 0.074 & 0.070 & 0.096 \\
\hline 1973 & 0.067 & 0.065 & 0.085 \\
\hline 1974 & 0.060 & 0.060 & 0.077 \\
\hline 1975 & 0.064 & 0.061 & 0.096 \\
\hline 1976 & 0.066 & 0.066 & 0.101 \\
\hline 1977 & 0.066 & 0.062 & 0.094 \\
\hline 1978 & 0.062 & 0.058 & 0.091 \\
\hline 1979 & 0.065 & 0.068 & 0.088 \\
\hline 1980 & 0.071 & 0.067 & 0.109 \\
\hline 1981 & 0.097 & 0.070 & 0.123 \\
\hline 1982 & 0.118 & 0.089 & 0.120 \\
\hline 1983 & 0.120 & 0.112 & 0.161 \\
\hline 1984 & 0.180 & 0.148 & 0.124 \\
\hline 1985 & 0.190 & 0.138 & 0.128 \\
\hline 1986 & 0.187 & 0.190 & 0.144 \\
\hline 1987 & 0.209 & 0.175 & 0.137 \\
\hline 1988 & 0.220 & 0.126 & 0.124 \\
\hline 1989 & 0.208 & 0.117 & 0.123 \\
\hline 1990 & 0.227 & 0.133 & 0.118 \\
\hline 1991 & 0.295 & 0.169 & 0.132 \\
\hline 1992 & 0.350 & 0.197 & 0.135 \\
\hline 1993 & 0.397 & 0.206 & 0.139 \\
\hline 1994 & 0.363 & 0.171 & 0.130 \\
\hline 1995 & 0.376 & 0.197 & 0.142 \\
\hline 1996 & 0.408 & 0.296 & 0.153 \\
\hline 1997 & 0.411 & 0.256 & 0.154 \\
\hline 1998 & 0.393 & 0.247 & 0.140 \\
\hline 1999 & 0.426 & 0.323 & 0.154 \\
\hline 2000 & 0.405 & 0.345 & 0.162 \\
\hline 2001 & 0.438 & 0.349 & 0.162 \\
\hline 2002 & 0.438 & 0.329 & 0.165 \\
\hline 2003 & 0.495 & 0.307 & 0.183 \\
\hline 2004 & 0.510 & 0.341 & 0.194 \\
\hline 2005 & 0.505 & 0.317 & 0.192 \\
\hline 2006 & 0.522 & 0.326 & 0.191 \\
\hline 2007 & 0.551 & 0.314 & 0.189 \\
\hline 2008 & 0.502 & 0.274 & 0.174 \\
\hline 2009 & 0.490 & 0.282 & 0.190 \\
\hline 2010 & 0.550 & 0.254 & 0.190 \\
\hline 2011 & 0.553 & 0.255 & 0.176 \\
\hline 2012 & 0.540 & 0.272 & 0.171 \\
\hline 2013 & 0.569 & 0.369 & 0.177 \\
\hline 2014 & 0.612 & 0.434 & 0.175 \\
\hline 2015 & 0.630 & 0.478 & 0.169 \\
\hline 2016 & 0.652 & 0.457 & 0.167 \\
\hline 2016 & $822 \%$ & $652 \%$ & $93 \%$ \\
\hline
\end{tabular}




\section{Table 4}

\section{Cash Flow and R\&D}

Panel A reports the joint distribution of cash flow and $R \& D$ deciles over the sample period. The full sample is 188,368 firm year observations over the period 1970-2016. Panel B reports average cash holdings by cash flow decile for the top two deciles of R\&D.

Panel A: Joint Distribution of Cash Flow and R\&D Deciles

\begin{tabular}{cccccccccccc} 
& \multicolumn{3}{c}{ Lowest CF } & \multicolumn{1}{c}{ Highest CF } \\
\cline { 3 - 12 } & 1 & 1 & 2 & 3 & 4 & 5 & 6 & 7 & 8 & 9 & 10 \\
\cline { 3 - 13 } R\&D & $0.5 \%$ & $0.8 \%$ & $1.1 \%$ & $1.2 \%$ & $1.4 \%$ & $1.3 \%$ & $1.1 \%$ & $1.1 \%$ & $1.0 \%$ & $0.7 \%$ \\
& 2 & $0.4 \%$ & $0.8 \%$ & $0.9 \%$ & $1.1 \%$ & $1.3 \%$ & $1.3 \%$ & $1.3 \%$ & $1.3 \%$ & $1.0 \%$ & $0.8 \%$ \\
& 3 & $0.5 \%$ & $0.7 \%$ & $0.9 \%$ & $1.0 \%$ & $1.0 \%$ & $1.3 \%$ & $1.4 \%$ & $1.3 \%$ & $1.1 \%$ & $0.8 \%$ \\
& 4 & $0.6 \%$ & $0.9 \%$ & $1.0 \%$ & $1.0 \%$ & $1.0 \%$ & $1.2 \%$ & $1.2 \%$ & $1.2 \%$ & $1.0 \%$ & $0.9 \%$ \\
& 5 & $0.7 \%$ & $0.9 \%$ & $1.0 \%$ & $1.0 \%$ & $1.0 \%$ & $1.0 \%$ & $1.1 \%$ & $1.1 \%$ & $1.1 \%$ & $1.0 \%$ \\
& 6 & $0.8 \%$ & $1.1 \%$ & $1.1 \%$ & $0.9 \%$ & $0.9 \%$ & $1.0 \%$ & $1.0 \%$ & $1.0 \%$ & $1.1 \%$ & $1.1 \%$ \\
& 7 & $0.9 \%$ & $1.2 \%$ & $1.0 \%$ & $0.9 \%$ & $0.8 \%$ & $0.9 \%$ & $1.0 \%$ & $1.0 \%$ & $1.1 \%$ & $1.2 \%$ \\
& 8 & $1.3 \%$ & $1.5 \%$ & $1.0 \%$ & $0.8 \%$ & $0.7 \%$ & $0.8 \%$ & $0.8 \%$ & $0.8 \%$ & $1.0 \%$ & $1.1 \%$ \\
& 9 & $2.6 \%$ & $1.7 \%$ & $0.9 \%$ & $0.6 \%$ & $0.6 \%$ & $0.5 \%$ & $0.6 \%$ & $0.7 \%$ & $0.8 \%$ & $1.0 \%$ \\
& 10 & $5.8 \%$ & $1.1 \%$ & $0.4 \%$ & $0.3 \%$ & $0.3 \%$ & $0.3 \%$ & $0.3 \%$ & $0.4 \%$ & $0.4 \%$ & $0.8 \%$
\end{tabular}

Panel B: Average Cash Holdings for High R\&D Firms

\begin{tabular}{ccccc} 
& & $1970-1979$ & $2007-2016$ & Growth \\
\cline { 3 - 5 } & 1 & 0.07 & 0.59 & $744 \%$ \\
Cash Flow & 4 & 0.07 & 0.29 & $336 \%$ \\
Decile & 5 & 0.07 & 0.17 & $153 \%$ \\
& 5 & 0.07 & 0.13 & $82 \%$ \\
& 6 & 0.08 & 0.11 & $57 \%$ \\
& 7 & 0.09 & 0.11 & $29 \%$ \\
& 8 & 0.10 & 0.12 & $35 \%$ \\
& 9 & 0.12 & 0.13 & $26 \%$ \\
& 10 & 0.15 & 0.15 & $27 \%$ \\
& & 0.22 & $43 \%$
\end{tabular}




\section{Table 5}

\section{Cash Holdings in First Year of Negative Cash Flow}

This table reports median values of cash/assets observed in the first year that the firm reports negative cash flow. The subgroups are formed for each decade based on the persistence of negative cash flows and cash flow history. The full sample is 188,368 firm year observations over the period 1970-2016. The Persistent category is made up of firms that are entering a run of negative cash flow that is at least three years in duration. The Transitory subgroup is made up of firms that return to positive cash flow the following year. New Firms are those that are less than three years old. Fallen Angels are firms that reported at least five years of positive cash flow before entering the negative cash flow sample.

\section{Persistent Transitory}

New Firms Fallen Angels New Firms Fallen Angels

$\begin{array}{llllll}1970 \mathrm{~s} & 0.040 & 0.046 & & 0.044 & 0.043 \\ 1980 \mathrm{~s} & 0.118 & 0.075 & & 0.080 & 0.055 \\ 1990 \mathrm{~s} & 0.386 & 0.359 & & 0.128 & 0.091 \\ 2000 \mathrm{~s} & 0.553 & 0.409 & & 0.157 & 0.111\end{array}$


Table 6

Proceeds from the Sale of Debt, Equity and PPE

This table reports the average annual proceeds from equity issuance, debt issuance, and the sale of fixed assets, scaled by total assets, for firms in each cash flow decile. The full sample is 188,368 firm year observations over the period 1970-2016. The first ten years and last ten years of the sample are reported for comparis on.

1970-79

Net Equity Net Debt Sale of PPE

/Assets

$1 \longdiv { 0 . 0 1 0 \quad 0 . 0 1 2 } 0 . 0 1 6$

$2 \quad 0.002$

$3 \quad 0.003$

0.024

0.025

Cash Flow 5

Decile

0.011

0.009

0.009

0.009

0.009
0.023

$4 \quad 0.002$

0.027

0.023

0.021

0.020

0.023

$\begin{array}{llll}10 & 0.042 & 0.011 & 0.012\end{array}$

0.009

0.009

0.009

$\begin{array}{llll}10 & 0.042 & 0.011 & 0.012\end{array}$

2007-16

Net Equity Net Debt Sale of PPE

\begin{tabular}{crr} 
/Assets & /Assets & \multicolumn{1}{c}{ /Assets } \\
\hline 0.378 & 0.021 & 0.002 \\
0.144 & 0.022 & 0.003 \\
0.052 & 0.020 & 0.003 \\
0.025 & 0.025 & 0.003 \\
0.009 & 0.021 & 0.003 \\
0.005 & 0.014 & 0.003 \\
$(0.001)$ & 0.010 & 0.003 \\
$(0.006)$ & 0.006 & 0.003 \\
$(0.016)$ & 0.001 & 0.004 \\
$(0.028)$ & $(0.014)$ & 0.003
\end{tabular}


Table 7

\section{Equity Issuance Frequency}

This table reports the average number of firm-initiated equity issuances per firm per year, compiled from quarterly data. Quarterly issuance data is available over the period 1985-2016.

\begin{tabular}{crrrrr} 
& & $1985-1989$ & $1990-1999$ & $2000-2009$ & $2010-2016$ \\
\cline { 3 - 6 } & 1 & 0.41 & 0.73 & 0.73 & 0.93 \\
& 2 & 0.29 & 0.49 & 0.44 & 0.53 \\
Cash Flow & 3 & 0.22 & 0.34 & 0.27 & 0.24 \\
Decile & 4 & 0.21 & 0.26 & 0.20 & 0.15 \\
& 6 & 0.19 & 0.22 & 0.15 & 0.12 \\
& 7 & 0.18 & 0.18 & 0.13 & 0.12 \\
& 8 & 0.16 & 0.15 & 0.11 & 0.08 \\
& 9 & 0.19 & 0.12 & 0.09 & 0.07 \\
& 10 & 0.23 & 0.12 & 0.08 & 0.06 \\
& 10 & 0.31 & 0.12 & 0.08 & 0.07
\end{tabular}


Table 8

\section{Equity Issuance Mechanis ms}

This table reports the proportion of seasoned equity issuances that are public versus private placements. The full sample is 188,368 firm year observations over the period 1970-2016. Data on equity issuance mechanisms is available from 1995 to 2013.

\begin{tabular}{|c|c|c|c|c|}
\hline \multirow[b]{2}{*}{ Year } & \multicolumn{2}{|c|}{ Negative CF } & \multicolumn{2}{|c|}{ Positive CF } \\
\hline & Public & Private & Public & Private \\
\hline 1995 & $77 \%$ & $23 \%$ & $95 \%$ & $5 \%$ \\
\hline 1996 & $80 \%$ & $20 \%$ & $95 \%$ & $5 \%$ \\
\hline 1997 & $60 \%$ & $40 \%$ & $94 \%$ & $6 \%$ \\
\hline 1998 & $45 \%$ & $55 \%$ & $96 \%$ & $4 \%$ \\
\hline 1999 & $40 \%$ & $60 \%$ & $91 \%$ & $9 \%$ \\
\hline 2000 & $30 \%$ & $70 \%$ & $77 \%$ & $23 \%$ \\
\hline 2001 & $21 \%$ & $79 \%$ & $67 \%$ & $33 \%$ \\
\hline 2002 & $16 \%$ & $84 \%$ & $72 \%$ & $28 \%$ \\
\hline 2003 & $19 \%$ & $81 \%$ & $64 \%$ & $36 \%$ \\
\hline 2004 & $22 \%$ & $78 \%$ & $64 \%$ & $36 \%$ \\
\hline 2005 & $22 \%$ & $78 \%$ & $60 \%$ & $40 \%$ \\
\hline 2006 & $20 \%$ & $80 \%$ & $62 \%$ & $38 \%$ \\
\hline 2007 & $19 \%$ & $81 \%$ & $57 \%$ & $43 \%$ \\
\hline 2008 & $14 \%$ & $86 \%$ & $46 \%$ & $54 \%$ \\
\hline 2009 & $12 \%$ & $88 \%$ & $67 \%$ & $33 \%$ \\
\hline 2010 & $12 \%$ & $88 \%$ & $51 \%$ & $49 \%$ \\
\hline 2011 & $7 \%$ & $93 \%$ & $58 \%$ & $43 \%$ \\
\hline 2012 & $9 \%$ & $91 \%$ & $51 \%$ & $49 \%$ \\
\hline 2013 & $12 \%$ & $88 \%$ & $71 \%$ & $29 \%$ \\
\hline
\end{tabular}


Table 9

Annual Burn Rate for Equity Is suers

This table reports the percentage of assets depleted annually by equity issuers with positive burn rates. Burn rate is defined as [-Operating Cash Flow+dividends+capital expenditures]. The full sample is 188,368 firm year observations over the period 1970-2016.

\begin{tabular}{lr}
\multicolumn{1}{c}{ Period } & \% burned \\
\hline $1971-75$ & $8.9 \%$ \\
$1976-80$ & $9.3 \%$ \\
$1981-85$ & $16.3 \%$ \\
$1986-90$ & $15.0 \%$ \\
$1991-95$ & $14.7 \%$ \\
$1996-2000$ & $19.9 \%$ \\
$2001-05$ & $22.3 \%$ \\
$2006-10$ & $23.8 \%$ \\
$2011-16$ & $26.8 \%$
\end{tabular}


Table 10

Determinants of cash holdings

This table reports results from OLS regressions of cash holdings (cash/assets) on various determinants. The full sample is 188,368 firm year observations over the period 1970-2016. Columns 1,3, and 5 use a linear specification for cash flow while columns 2, 4, and 6 allow for nonlinearity when earnings are negative by adding an indicator of negative earnings and an interaction that takes the value of CF/assets when it is negative and zero otherwise. Variables are defined in the appendix. Standard errors are clustered by firm and year. *, **, and *** indicate significance at the $10 \%, 5 \%$ and $1 \%$ levels respectively.

\begin{tabular}{|c|c|c|c|c|c|c|c|c|c|c|c|c|c|c|c|c|}
\hline \multirow{3}{*}{ Cash Flow } & \multicolumn{2}{|l|}{ (1) } & \multicolumn{2}{|l|}{ (2) } & \multicolumn{2}{|l|}{ (3) } & \multicolumn{2}{|l|}{ (4) } & \multicolumn{2}{|l|}{ (5) } & \multicolumn{2}{|l|}{ (6) } & \multicolumn{2}{|l|}{ (7) } & \multicolumn{2}{|l|}{ (8) } \\
\hline & -0.110 & $* * *$ & 0.149 & *** & -0.11 & $* * *$ & 0.153 & $* * *$ & -0.098 & $* * *$ & 0.144 & $* * *$ & -0.069 & $* * *$ & 0.181 & $* * *$ \\
\hline & $(<0.001)$ & & $(<0.001)$ & & $(<0.001)$ & & $(<0.001)$ & & $(<0.001)$ & & $(<0.001)$ & & $(<0.001)$ & & $(<0.001)$ & \\
\hline \multirow[t]{2}{*}{$\mathrm{I}(\mathrm{CF}<0)$} & & & 0.041 & $* * *$ & & & 0.040 & $* * *$ & & & 0.038 & $* * *$ & & & 0.036 & $* * *$ \\
\hline & & & $(<0.001)$ & & & & $(<0.001)$ & & & & $(<0.001)$ & & & & $(<0.001)$ & \\
\hline \multirow{2}{*}{$\mathrm{CF} \times \mathrm{I}(\mathrm{CF}<0)$} & & & -0.337 & $* * *$ & & & -0.336 & $* * *$ & & & -0.309 & $* * *$ & & & -0.316 & $* * *$ \\
\hline & & & $(<0.001)$ & & & & $(<0.001)$ & & & & $(<0.001)$ & & & & $(<0.001)$ & \\
\hline \multirow[t]{2}{*}{ Size } & -0.005 & $* * *$ & -0.002 & $*$ & -0.004 & $* * *$ & -0.002 & $* * *$ & -0.005 & $* * *$ & -0.003 & $* * *$ & -0.004 & $* * *$ & -0.003 & $* * *$ \\
\hline & $(<0.001)$ & & $(0.068)$ & & $(<0.001)$ & & $(<0.001)$ & & $(<0.001)$ & & $(<0.001)$ & & $(<0.001)$ & & $(<0.001)$ & \\
\hline \multirow[t]{2}{*}{ Industry CF Vol } & 0.531 & $* * *$ & 0.512 & $* * *$ & 0.565 & $* * *$ & 0.528 & $* * *$ & 0.258 & $* * *$ & 0.241 & $* * *$ & 0.535 & $* * *$ & 0.492 & $* * *$ \\
\hline & $(<0.001)$ & & $(<0.001)$ & & $(<0.001)$ & & $(<0.001)$ & & $(<0.001)$ & & $(<0.001)$ & & $(<0.001)$ & & $(<0.001)$ & \\
\hline \multirow[t]{2}{*}{ I(R\&D Intense) } & 0.065 & $* * *$ & 0.059 & $* * *$ & 0.063 & $* * *$ & 0.059 & $* * *$ & 0.062 & $* * *$ & 0.058 & $* * *$ & 0.047 & $* * *$ & 0.045 & $* * *$ \\
\hline & $(<0.001)$ & & $(<0.001)$ & & $(<0.001)$ & & $(<0.001)$ & & $(<0.001)$ & & $(<0.001)$ & & $(<0.001)$ & & $(<0.001)$ & \\
\hline \multirow[t]{2}{*}{$\mathrm{M} / \mathrm{B}$} & 0.028 & $* * *$ & 0.023 & $* * *$ & 0.028 & $* * *$ & 0.023 & $* * *$ & 0.026 & $* * *$ & 0.021 & $* * *$ & 0.03 & $* * *$ & 0.025 & $* * *$ \\
\hline & $(<0.001)$ & & $(<0.001)$ & & $(<0.001)$ & & $(<0.001)$ & & $(<0.001)$ & & $(<0.001)$ & & $(<0.001)$ & & $(<0.001)$ & \\
\hline \multirow[t]{2}{*}{ Cap Ex } & -0.205 & $* * *$ & -0.249 & $* * *$ & -0.209 & $* * *$ & -0.242 & $* * *$ & -0.238 & $* * *$ & -0.269 & $* * *$ & -0.23 & $* * *$ & -0.267 & $* * *$ \\
\hline & $(<0.001)$ & & $(<0.001)$ & & $(<0.001)$ & & $(<0.001)$ & & $(<0.001)$ & & $(<0.001)$ & & $(<0.001)$ & & $(<0.001)$ & \\
\hline \multirow[t]{2}{*}{ Leverage } & -0.275 & $* * *$ & -0.268 & $* * *$ & -0.276 & $* * *$ & -0.269 & $* * *$ & -0.279 & $* * *$ & -0.273 & $* * *$ & -0.246 & $* * *$ & -0.241 & $* * *$ \\
\hline & $(<0.001)$ & & $(<0.001)$ & & $(<0.001)$ & & $(<0.001)$ & & $(<0.001)$ & & $(<0.001)$ & & $(<0.001)$ & & $(<0.001)$ & \\
\hline \multirow[t]{2}{*}{ I(Dividend) } & -0.032 & $* * *$ & -0.034 & $* * *$ & -0.032 & $* * *$ & -0.032 & $* * *$ & -0.028 & $* * *$ & -0.027 & $* * *$ & -0.026 & $* * *$ & -0.027 & $* * *$ \\
\hline & $(<0.001)$ & & $(<0.001)$ & & $(<0.001)$ & & $(<0.001)$ & & $(<0.001)$ & & $(<0.001)$ & & $(<0.001)$ & & $(<0.001)$ & \\
\hline \multirow[t]{2}{*}{ Constant } & 0.168 & $* * *$ & 0.128 & $* * *$ & 0.165 & $* * *$ & 0.129 & $* * *$ & 0.181 & $* * *$ & 0.162 & $* * *$ & 0.140 & $* * *$ & 0.114 & $* * *$ \\
\hline & $(<0.001)$ & & $(<0.001)$ & & $(<0.001)$ & & $(<0.001)$ & & $(<0.001)$ & & $(<0.001)$ & & $(<0.001)$ & & $(<0.001)$ & \\
\hline Fixed Effects & None & & None & & Year & & Year & & Year, Industry & & Year, Industry & & $F M$ & & $F M$ & \\
\hline $\mathrm{N}$ & 186,715 & & 186,715 & & 186,715 & & 186,715 & & 186,715 & & 186,715 & & 186,715 & & 186,715 & \\
\hline $\mathrm{R} 2$ & 0.403 & & 0.417 & & 0.407 & & 0.420 & & 0.434 & & 0.445 & & 0.400 & & 0.414 & \\
\hline
\end{tabular}


Table 11

Numerical example: What drives growth in cash holdings in low cash flow firms?

This table reports predicted cash holdings for the median firm characteristics from the lowest decile of $\mathrm{CF} /$ assets during the periods (i) 1970-74 and (ii) 2012-2016 using coefficients from OLS regressions of cash holdings (cash/assets) on various determinants defined in the appendix. The full sample is 188,368 firm year observations over the period 1970-2016. Predicted cash is the product of the coefficients and median values for each respective subperiod.

\begin{tabular}{|c|c|c|c|c|c|c|c|c|}
\hline & \multicolumn{6}{|c|}{ Median Values } & & \\
\hline & \multicolumn{2}{|c|}{ Coefficients } & \multicolumn{2}{|c|}{$\mathrm{CF}<0$} & \multicolumn{2}{|c|}{ Predicted Cash } & & \\
\hline & 1970-1974 & $2012-2016$ & 1970-1974 & $2012-2016$ & (1) & $(2)$ & & \\
\hline Cash Flow & 0.118 & 0.323 & -0.069 & -0.177 & $(0.008)$ & $(0.057)$ & & \\
\hline $\mathrm{I}(\mathrm{CF}<0)$ & 0.015 & 0.062 & 1 & 1 & 0.015 & 0.062 & & \\
\hline Cash Flow x I $(\mathrm{CF}<0)$ & -0.142 & -0.576 & -0.069 & -0.177 & 0.010 & 0.102 & & \\
\hline Industry CF Vol & 0.250 & 0.416 & 0.032 & 0.139 & 0.008 & 0.058 & & \\
\hline Size & -0.004 & 0.000 & 2.000 & 4.399 & $(0.009)$ & $(0.001)$ & & \\
\hline $\mathrm{R} \& \mathrm{D}$ & -0.019 & 0.124 & 0.000 & 1.000 & - & 0.124 & & \\
\hline $\mathrm{M} / \mathrm{B}$ & 0.022 & 0.020 & 0.949 & 2.009 & 0.021 & 0.039 & & \\
\hline Cap Ex & -0.083 & -0.401 & 0.040 & 0.012 & $(0.003)$ & $(0.005)$ & & \\
\hline Leverage & -0.154 & -0.214 & 0.385 & 0.089 & $(0.059)$ & $(0.019)$ & & \\
\hline I(Dividend) & -0.003 & -0.041 & 0 & 0 & - & - & & \\
\hline \multirow[t]{2}{*}{ Constant } & 0.096 & 0.103 & & & 0.096 & 0.103 & & \\
\hline & & & & & & & Increase & $\%$ \\
\hline Predicted cash & & & & & 0.070 & 0.406 & 0.336 & \\
\hline Contribution from cas & low level & & & & 0.017 & 0.107 & 0.090 & $27 \%$ \\
\hline Contribution from cas & low volatility & & & & 0.008 & 0.058 & 0.050 & $15 \%$ \\
\hline
\end{tabular}




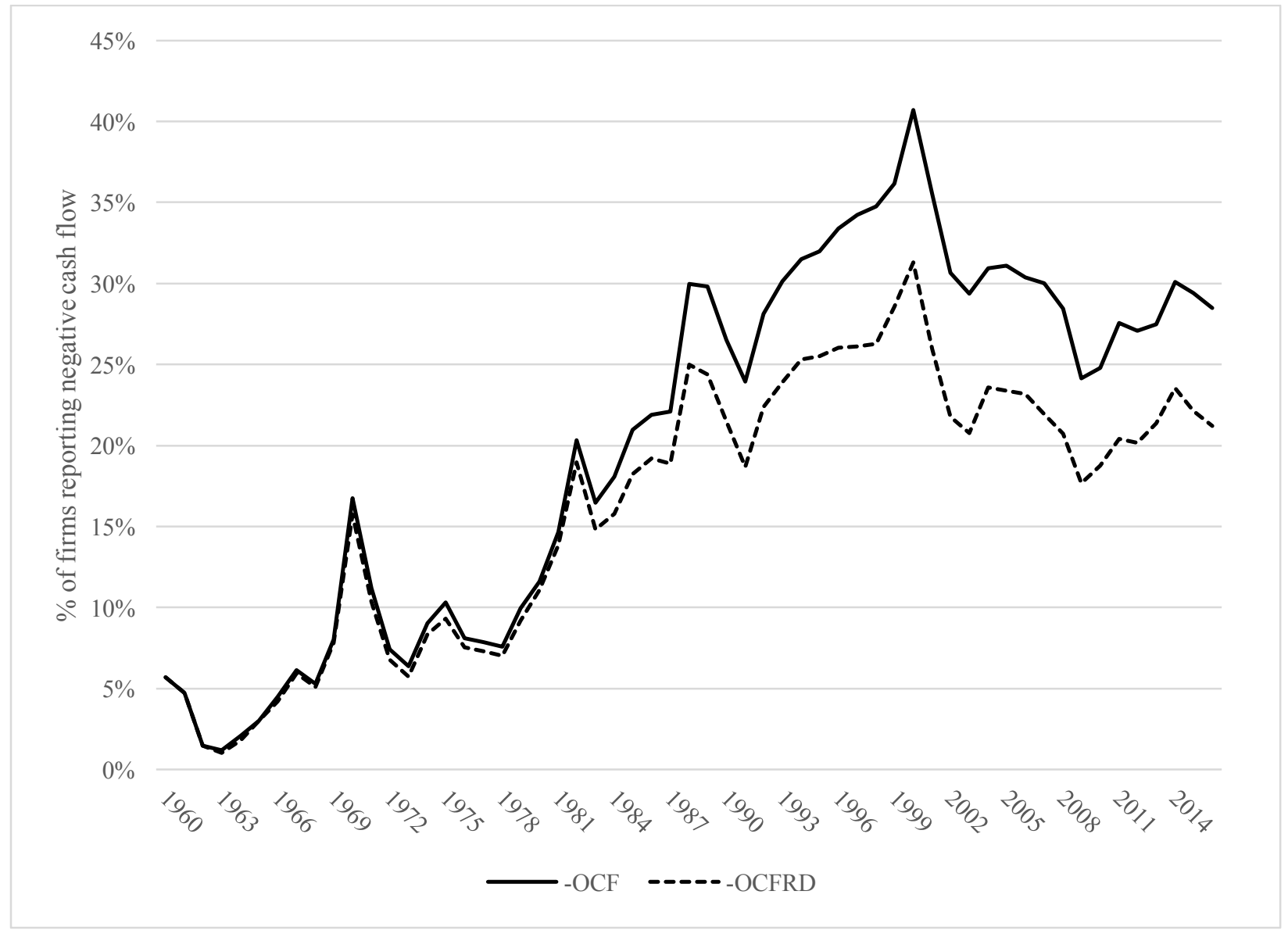

Figure 1. Prevalence of Negative Cash Flow. This chart reports the percentage of Compustat listed firms that report negative operating cash flow. -OCF is negative operating cash flow, -OCFRD is negative operating cash flow after adding back R\&D expense. Detailed variable descriptions are available in the appendix. 

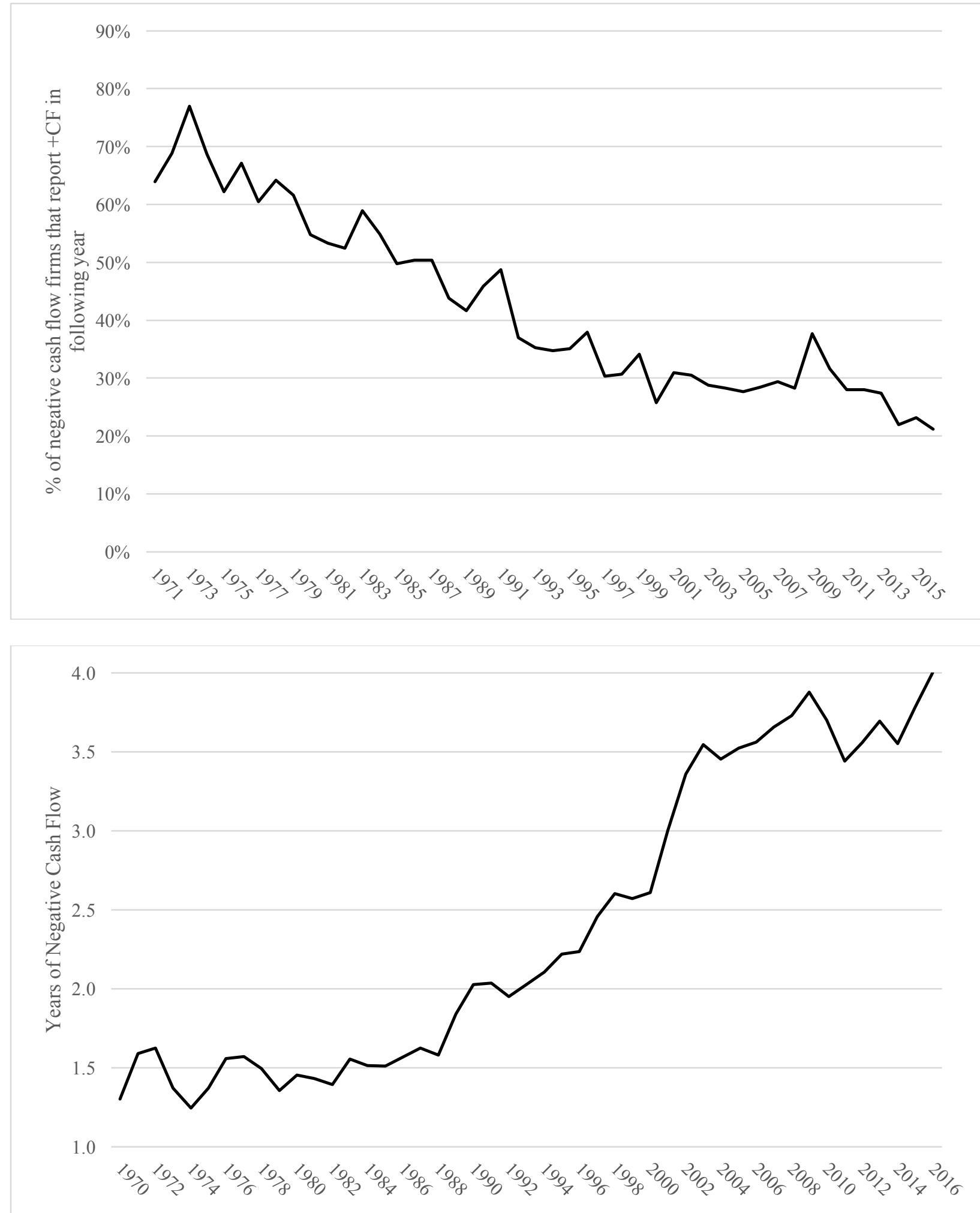

Figure 2. Persistence of Negative Cash Flow. Panel A: Proportion of Negative cash flow firms that report positive cash flow in the following year. Panel B: Average number of consecutive years of negative cash flow for firms that report negative cash flow. 


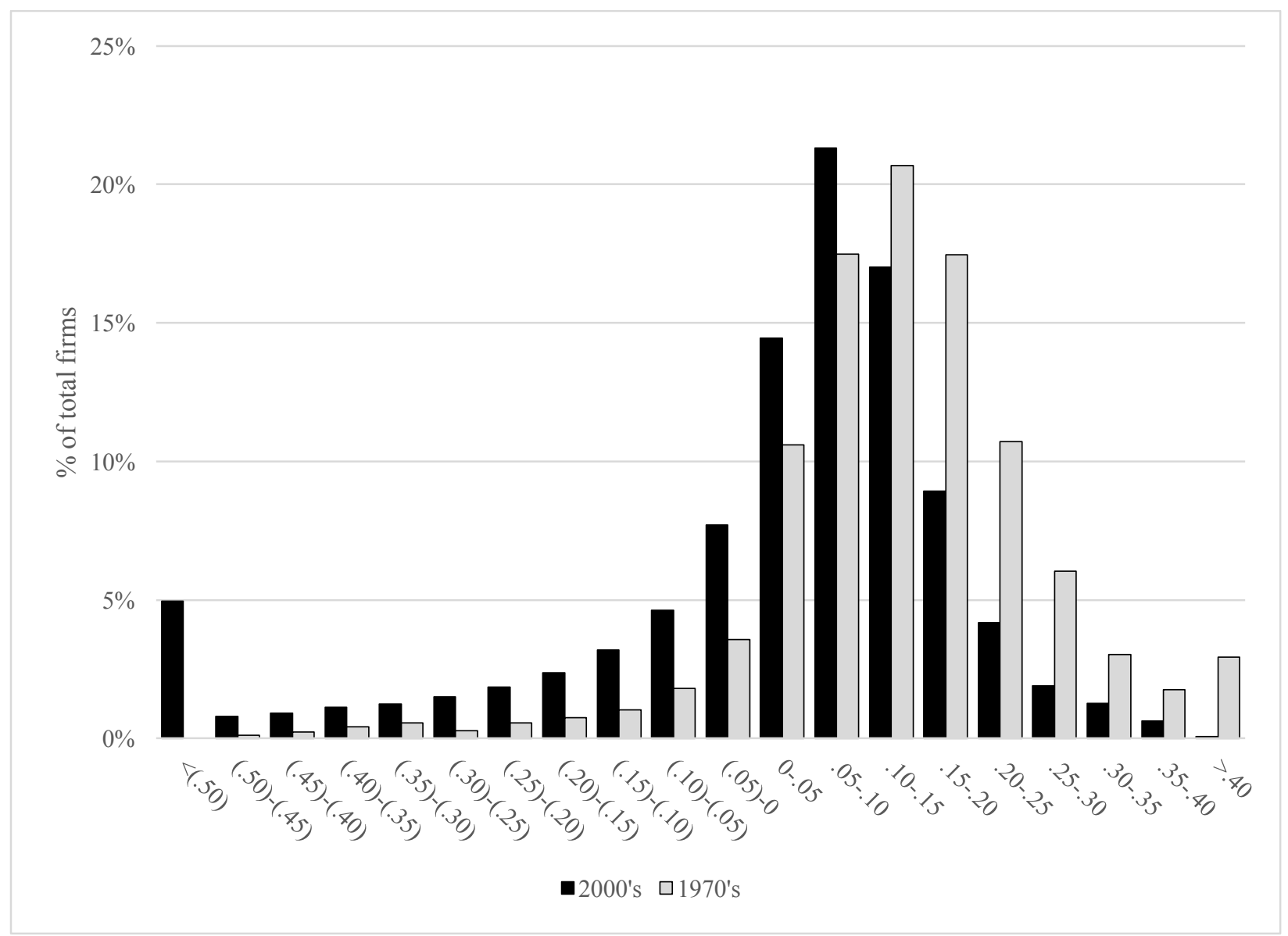

Figure 3. Distribution of Firms by Cash Flow over time. This chart reports the percentage of firm-year observations within each bin of operating cash flow during two subperiods: (i) 1970-79, (ii) 2000-2015. 


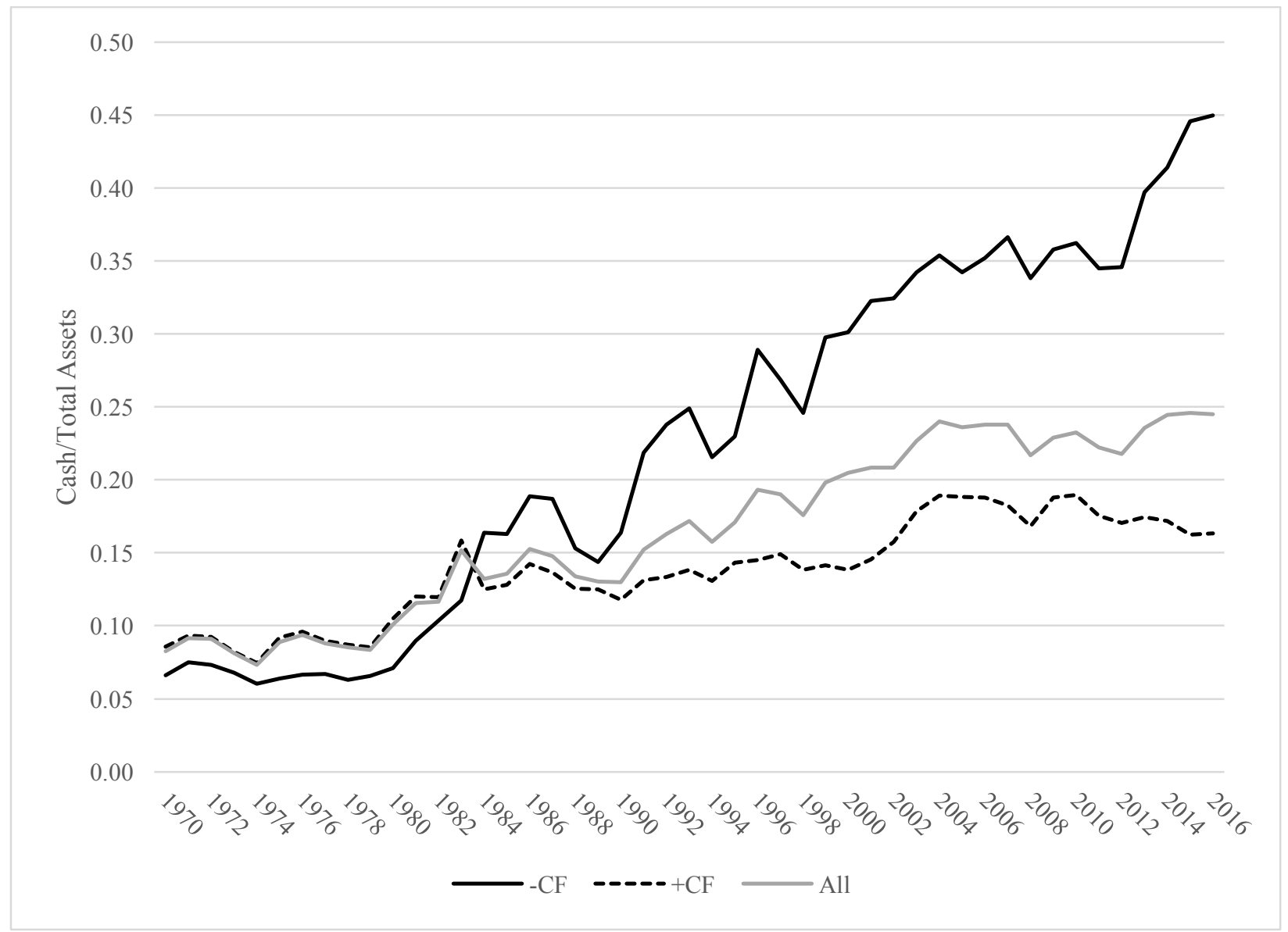

Figure 4. Evolution of Cash Holdings. This chart reports mean values of cash/total assets annually over 1970-2015 for the full sample (gray line) as well as two subsamples: positive cash flow firms (dotted line) and negative cash flow firms (solid black line). 


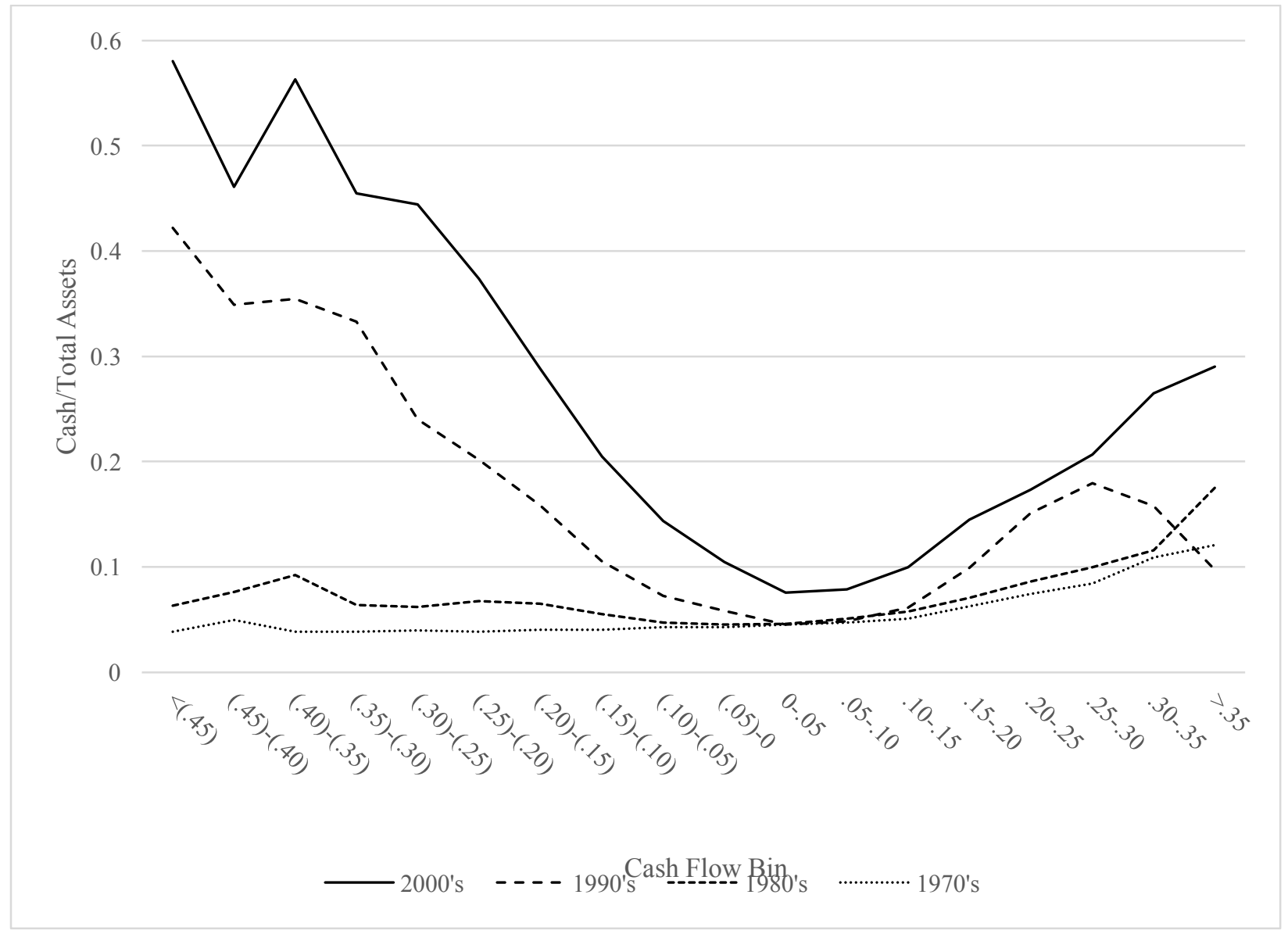

Figure 5. Convexity in the Relation between Cash Holdings and Cash Flow. This chart reports median values of cash/total assets for each bin of operating cash flow during four subperiods: (i) 1970-79, (ii) 198089, (iii) 1990-99, and (iv) 2000-2015. 


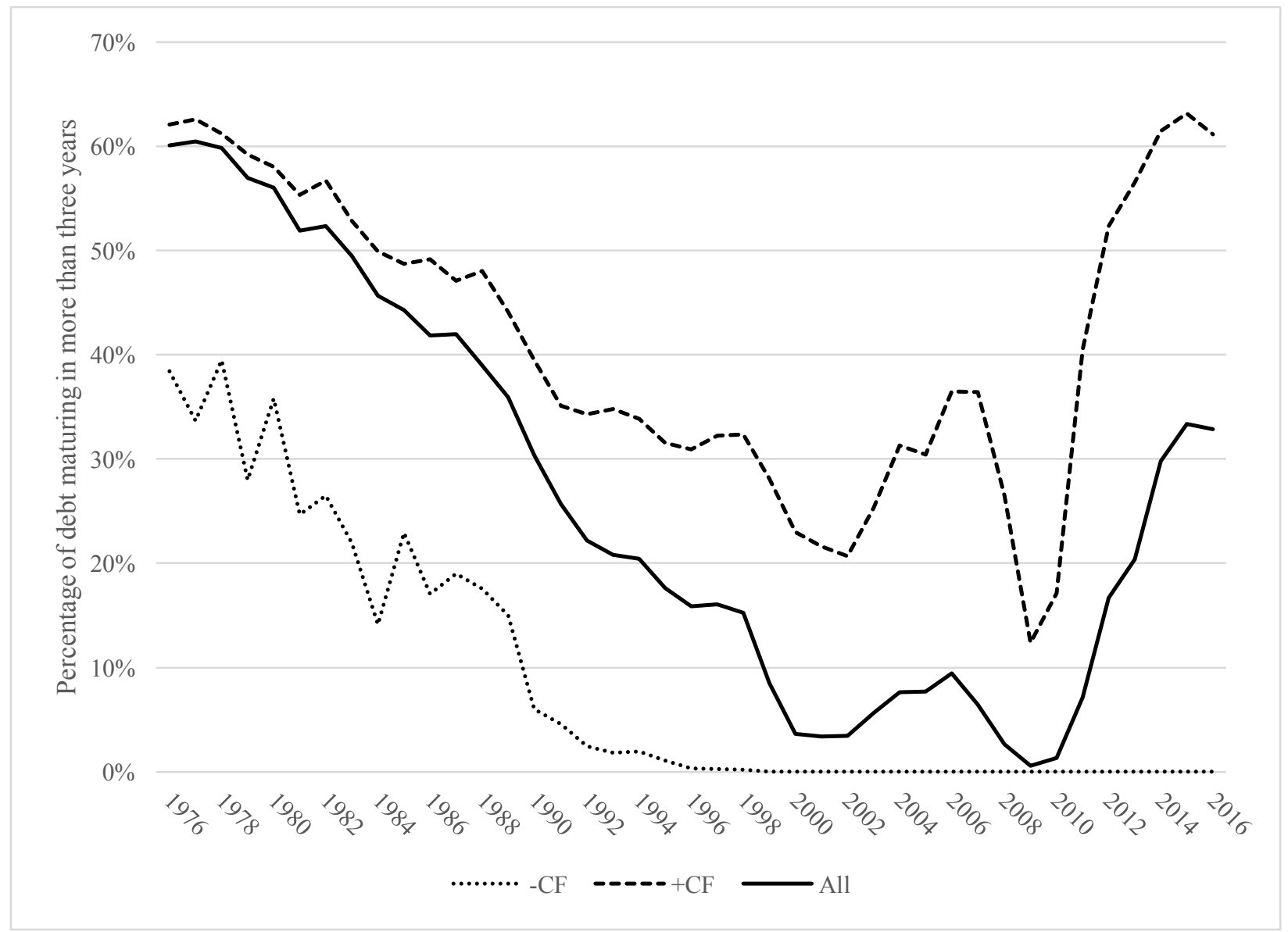

Figure 6. Debt maturity. This chart reports the median percentage of debt that matures in more than three years for the full sample, as well as the negative and positive cash flow subgroubs. 


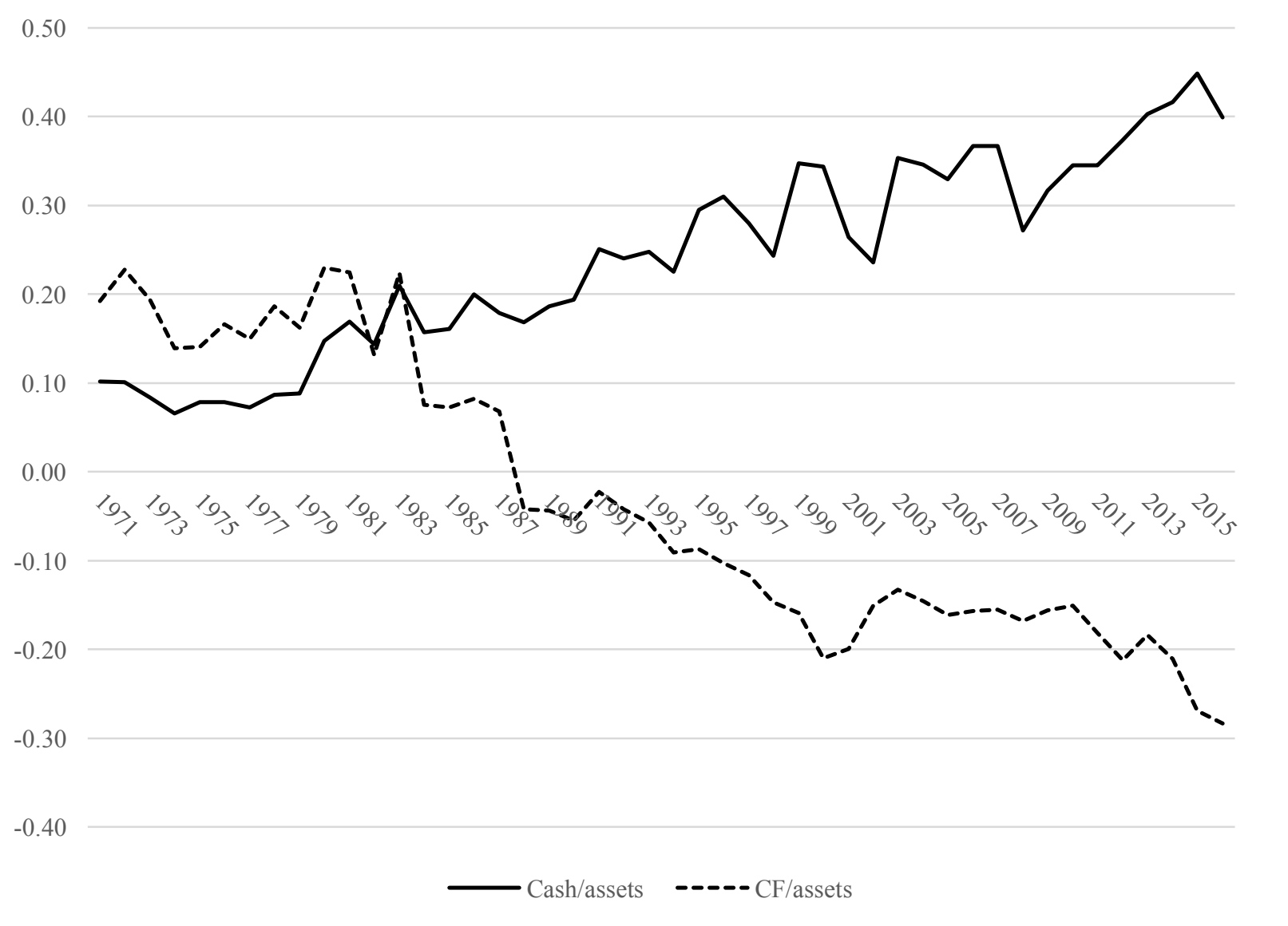

Figure 7. Equity Issuer Characteristics. This chart reports mean values of cash holdings and operating cash flow for all firms that initiate an equity issuance in a given year. 


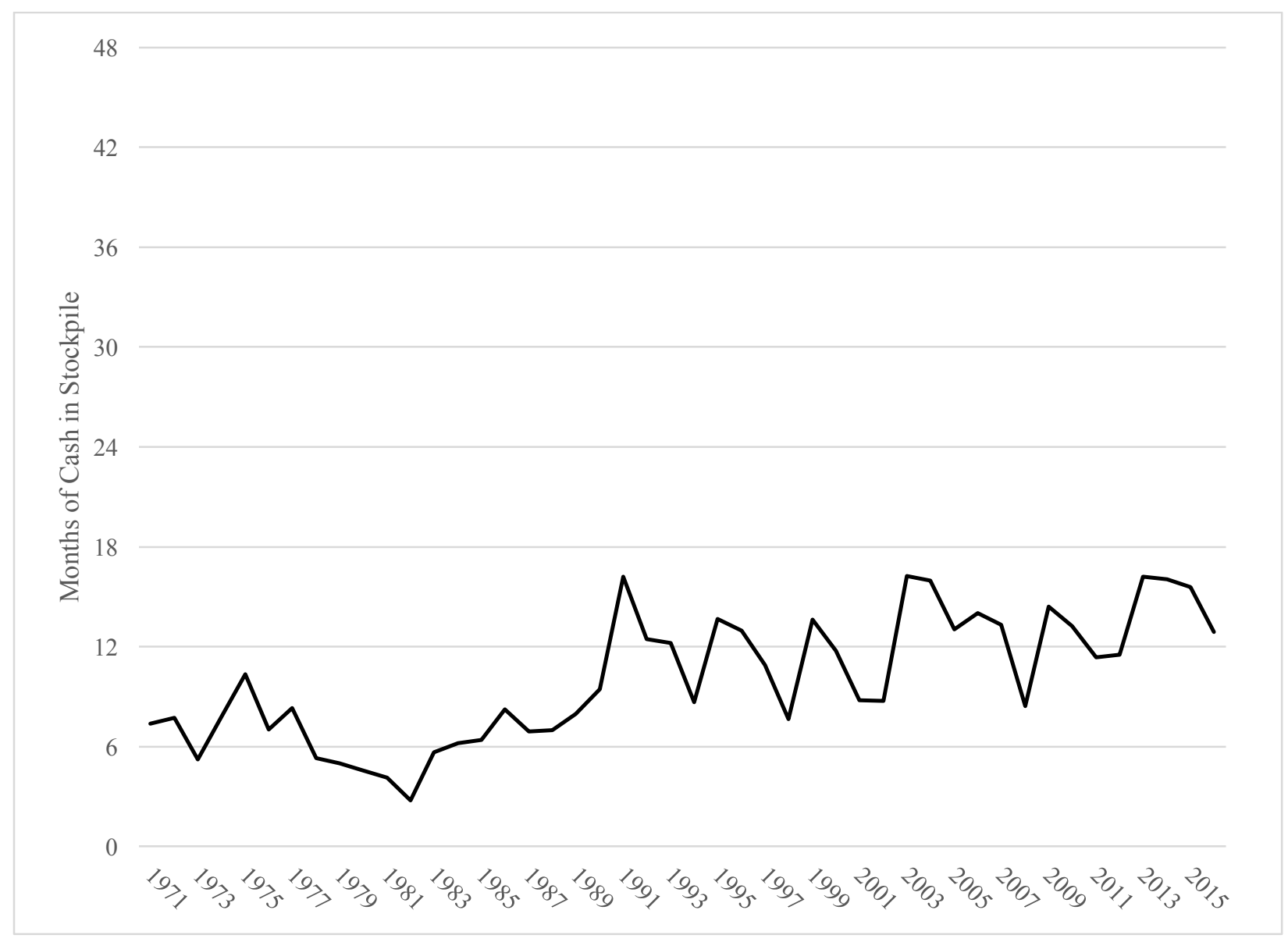

Figure 8. Median Runway for Equity Issuers with Negative Cash Flow. This chart reports the mean number of months of continued operations that could be sustained given the level of cash holdings immediately following the equity issue. The sample includes all firms that both initiate an equity issuance and report negative cash flow in a given year. 


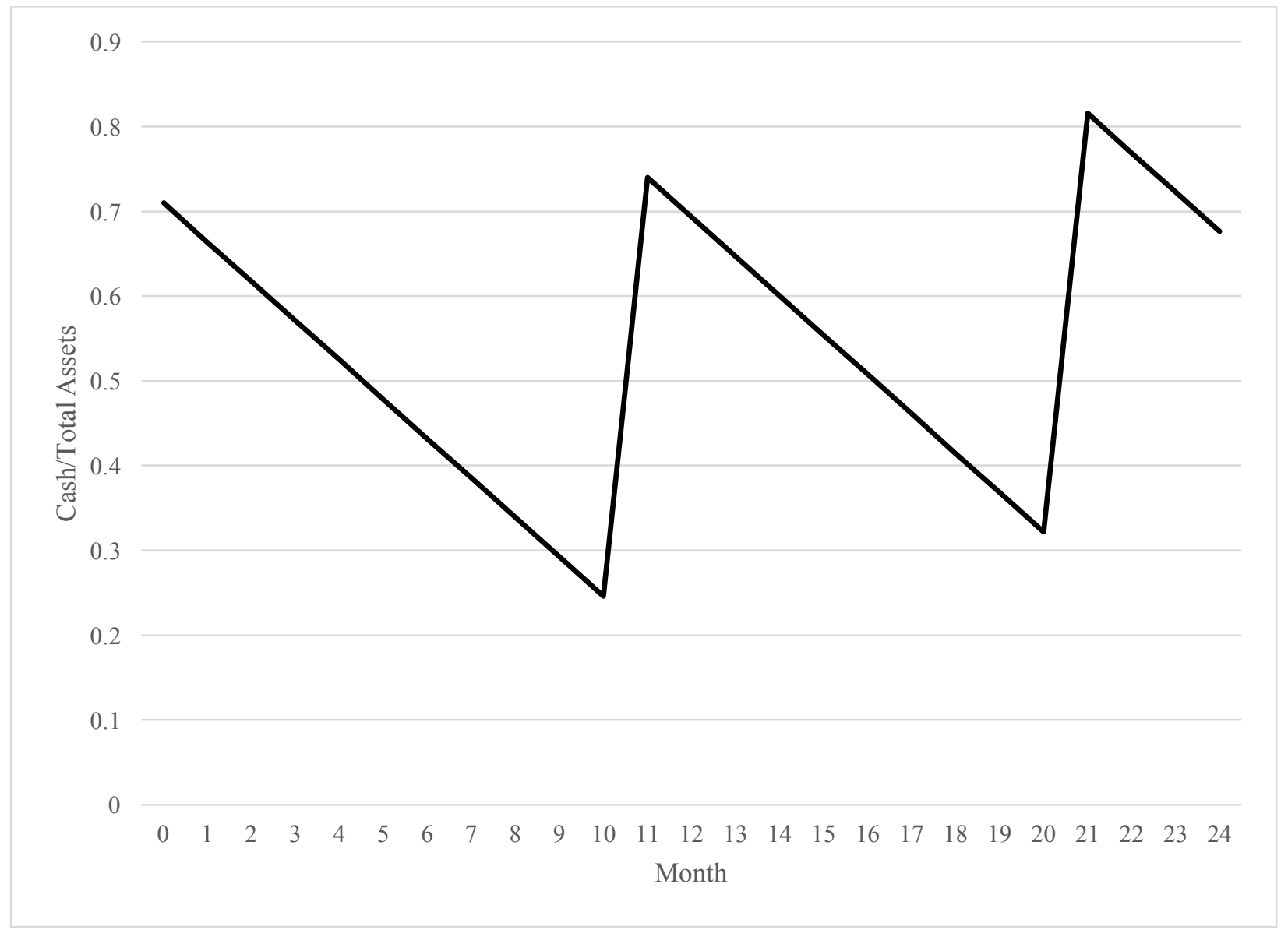

Figure 9. Simulated Cash Holdings of Equity Issuers. This chart reports a stylized model of the evolution of cash holdings over 24 months. Values are calibrated to observed average figures for high cash equity issuers over the last decade of the sample. 

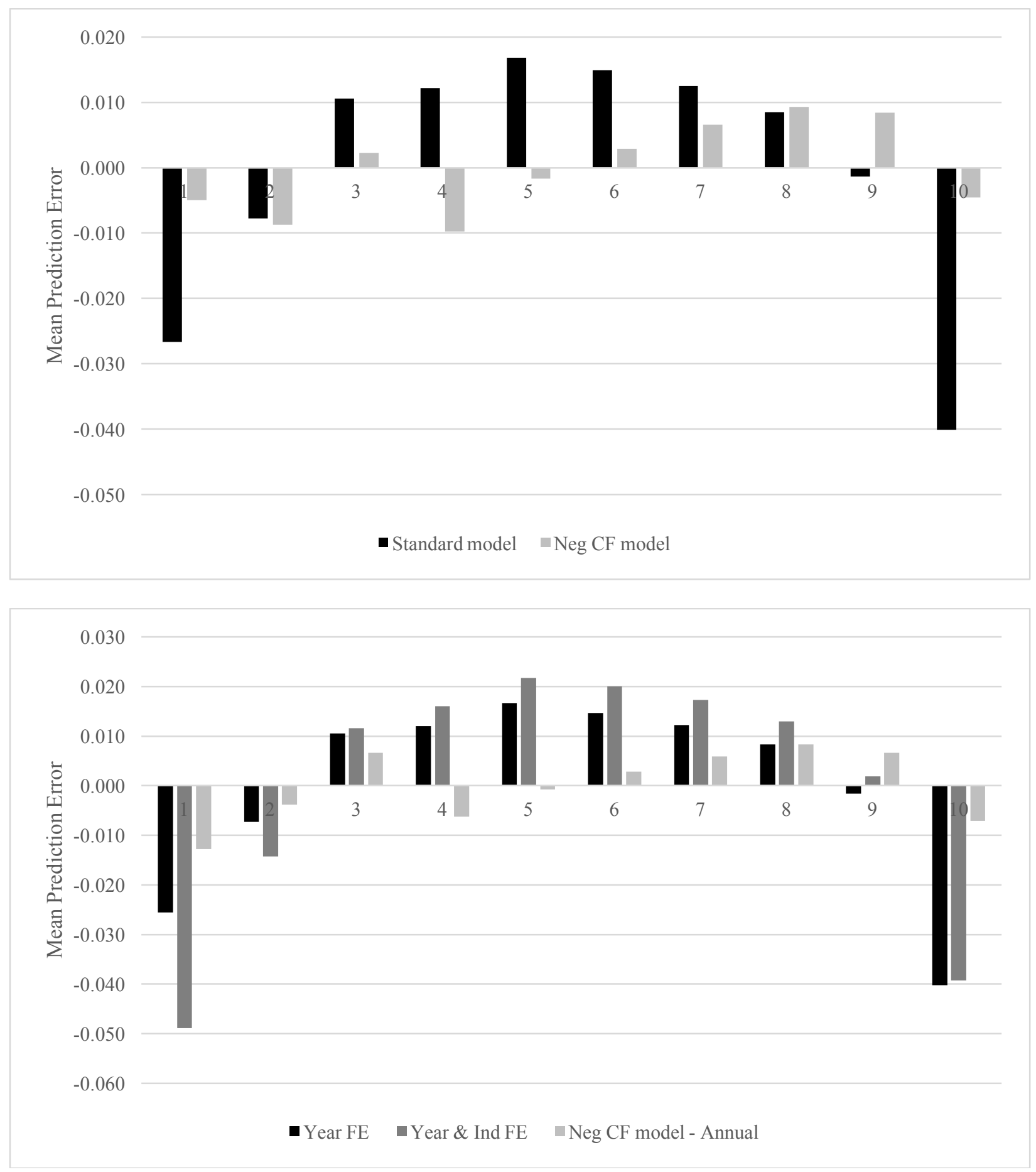

Figure 10. Prediction Error in Models of Cash Holdings. Panel A reports average prediction error from a standard model of cash/assets including cash flow, size, leverage, R\&D intensity, industry cash flow volatility, capital expenditures and market-to-book ratio. The second series in panel A adds an indicator variable for negative cash flow and an interaction between negative cash flow and level of cash flow. Panel $B$ reports prediction error from estimates using (i) the standard model with year fixed effects, (ii) year and industry fixed effects, and (iii) the negative earnings model from panel A estimated on annual cross sections. Both panels report average error sorted by cash flow decile where 1 is the lowest level of cash flow and 10 is the highest. 